\title{
An Account of the Works of Nektarios Protopsaltis and Nektarios Frimu in Manuscript no. 7 from the "Dumitru Staniloae" Ecumenical Library of the Metropolitan Church of Moldavia and Bukovina
}

\author{
IRINA ZAMFIRA DĂNILĂ \\ “George Enescu” National University of Arts Iasi \\ ROMANIA*
}

\begin{abstract}
The "Dumitru Staniloae" Ecumenical Library of the Metropolitan Church of Moldavia and Bukovina (reffered to below as LMCMB) from Iasi has an invaluable collection of theological books and documents, consisting of more than 100,000 items. The library also has an important number of rare books - 35 of which are psaltic music manuscripts. Manuscript no. 7 from LMCMB is a psaltic Antologhion with Chrysantine notation, written in Romanian using the Cyrillic alphabet. The copyist and the place where it was copied are unknown, but it is possible that it was written at Mount Athos, between 1877 and 1882 (Apud Bucescu, 2009, p. 108). Manuscript no. 7 mainly contains chants for various services, translated and adapted by Nektarios Protopsaltes (1804-1899). Nektarios was one of the best known psalm singers and Romanian composers, founder of a psaltic music school, who was active at the Holy Mountain in the second half of the nineteenth century. Manuscript no. 7 also contains a rarer variant of the Doxastikon Lord, the fallen woman, attributed to another Moldavian composer - Nektarios Frimu (†1856). Like Nektarios Protopsaltis, he was also born in Husi (Moldavia, Romania) - but lived and worked in Iasi. For his achievements, he is honoured with the title of "hierarch of Tripoleos". He authored the Anthology - Collection of psaltic chants for the Liturgy, (1840) and Collection of Psaltic Chants for Vespers and Matins (1846), one of the first works of its kind in Chrysantine notation in the Romanian language; these volumes were greatly valued during the second half of the nineteenth century. The present paper, which is part of the ampler project of cataloguing the entire collection of psaltic music manuscripts from LMCMB, focuses on the codicological presentation of the manuscript and its musical and liturgical content. The work will also present the authors, the Greek sources the chants were based on, also emphasizing the importance of this codex in the context of the LMCMB collection.
\end{abstract}

Keywords: Romanian antologhion, The "Dumitru Staniloae" Ecumenical Library of Metropolitan Church of Moldavia and Bukovina, Iasi, nineteenth century, Nektarios Protopsaltis, Nektarios Frimu.

\footnotetext{
*dzamfira@yahoo.com
} 


\section{Introduction}

The "Dumitru Staniloae” Ecumenical Library of the Metropolitan Church of Moldavia and Bukovina (reffered to below as LMCMB) from Iasi has an invaluable collection of theological books and documents, consisting of more than 100,000 items. The library also has an important number of rare books 35 of which are psaltic music manuscripts.

\subsection{The scopus of the study}

The present paper, which is part of the ampler project of cataloguing the entire collection of psaltic music manuscripts from LMCMB, focuses on the codicological presentation of the manuscript and its musical and liturgical content. The work will also present the authors, the Greek sources the chants were based on, also emphasizing the importance of this codex in the context of the LMCMB collection.

\section{The repertoire and the composers of chants in Ms. 7 LMCMB}

As it is a manuscript of the Antologhion type, Ms. 7 LMCMB contains a variety of songs from major Orthodox religious services: hymns for the Liturgy (great cherouvika), the Vespers (the glories and the eothina, the Psalm Blessed is the man, the antiphona, the polyeleoi) and Matins (Gospel Sundays stichera on the eight modes/ Eothina, the troparia for the services during the last week of the Holy Week). The manuscript also contains seven songs for two special services, the Akathist Hymn Our Lady and Protectress and the service dedicated to the miracle working icon of the Holy Virgin of the "Prodromos Hermitage" from the Holy Mountain (See in the Appendix of this study the cataloguing of Ms. 7).

The musical notation used in Ms. 7 LMCMB is the Chrysantine notation promoted at Constantinople starting 1814, the year of the reform of church music, and introduced almost simultaneously in the Romanian Principalities Moldavia and Țara Românească. The repertory reflects the new trends of the early 19th century in church music. Thus, works by 18th century composers are preferred, which are considered more traditional, such as Iakovos Protopsaltis (1740-1800). He was the disciple of Ioannis Protopsaltis and in turn held the positions conductor ("domestikos"), conductor of the choir members on the left side of the pew ("lampadarios") and protopsaltis (first chanter) of the Patriarchate of Constantinople. He was also a professor at the Patriarchal Music School, together with the great composers and psaltes Daniel Protopsaltis and Petros Lampadarios between 1764-1776, as well as Petros Vyzantios, in 1791. He spoke against the proposal to introduce a new simplified notation by Agapios Paliermos (in 1797). Iakovos Protopsaltis is considered a composer who did not readily accept innovations; thus, he did not agree with the new syllabic style ("in short", "syntoma”, exegetical) promoted by Petros the 
Lampadarios and his disciples. He sought to maintain in his works the old classic kalophonic ("embellished") style and his main work is Doxastarion", recorded by his apprentice, Georgios Kritos in koukouzelian (late mediobyzantine) musical notation. This reference work was transcribed in modern Chrysantine notation, by Hourmouzios Hartophilakos and published in the edition of Theodor Fokaefs in 1836 (Apud Oxford Music online, Iakovos Protopsaltis). In Ms. 7 LMCMB, the Theotokia on the eight modes can be found, accompanied by the line Glory be to the Father and to the Son and to the Holy Spirit, from the composition by Iakovos Protopsaltis, translated by Nektarios the Hermit into Romanian, in the version for the new notation by Hourmouzios Hartophilakos. The main feature of these songs is their common theme, of praise addressed to the the Holy Mother of God. In the musical adaptation in Romanian by Nektarios Protopsaltis, the tempo of the Theotokion is moderate, while the musical writing is in the sticheraric style.

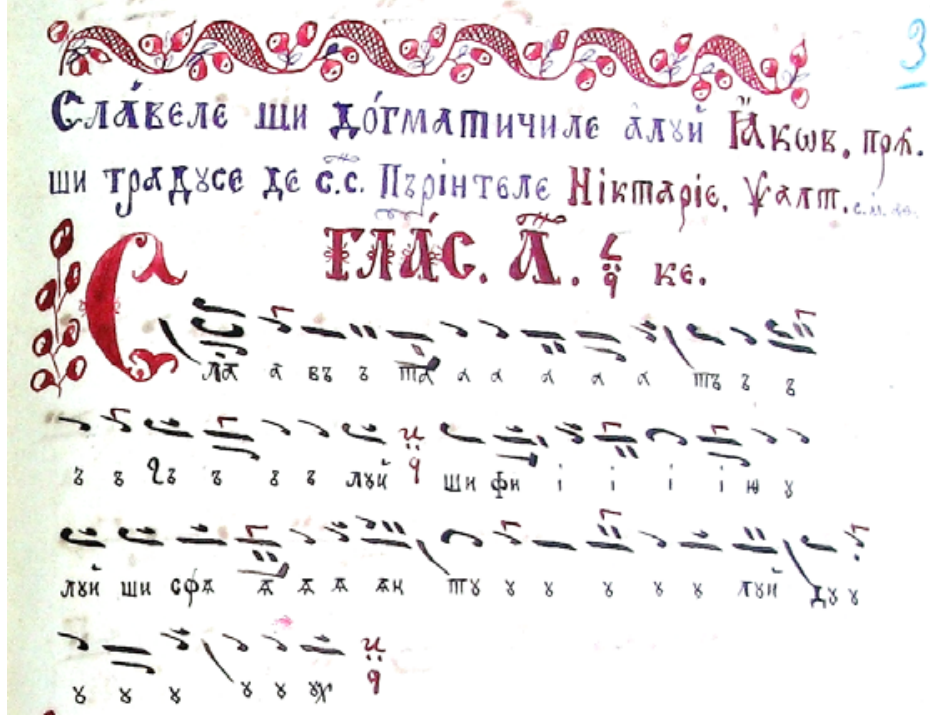

Fig. 1 Ms. 7 LMCMB, 1. 63, the title of the chapter: "The Glories and the Theotokia by Iakovos $\operatorname{Pr}[$ oto]ps[altis] [written?] and translated by. H. H. Father Niktarios Psaltes S. M. Athos. The $1^{\text {st }}$ mode I ke"

On reading the new collections of church music printed in the last 20 years in Romania (Buchet muzical athonit. Dumnezeiasca Liturghiel "A

\footnotetext{
${ }^{1}$ The Doxastarion is a collection of church music repertoire containing the Doxastika of the holidays throughout the year, organized according to the church year, starting on the 1st of September. The doxastikon means an ampler chant in the compositional style known as Sticheraric or papadic, preceded by "Glory to the Father and Son and Holy Spirit", which is usually sung on Vespers (e.g. the doxastikon of the Lord, we have cried unto You), either at Matins (for example, sticheron of the gospel read during the matins, also called "eothina").
} 
Musical collection of chants from the Mount Athos”, 2000, 2009), we have found that these variants of the Theotokia by Nektarios Protopsaltis have not yet been reprinted. For this reason, Ms. 7 LMCMB, along with other manuscripts found at the Holy Mountain, such as for example Ms. 93 from the Library of the Prodromos Romanian Hermitage (LPRH) - Vigiler, l. 136-161 (Vasile, 2008, p. 103), Ms. 1697 LPRH - Vigiler, l. 78-103 (Vasile, 2008, p. 121), Ms. 1698 LPRH - Antologhion, l. 177-198 (Vasile, 2008, p. 123), Ms. 1791 LPRH - Chants for the Liturgy, l. 40v-57 (Vasile, p. 180), Ms. 3045 LPRH - Vigiler, l. 83ㄴ-95 (Vasile, 2008, p. 232), Ms. 3612 LPRH - Vigiler, 1. 401-446 (Vasile, 2008, p. 281) etc. represent a potential source of repertoire that would help complete the variants of the Theotokia practiced as chants.

Another cycle of chants belonging to Iakovos Protopsaltis, translated by Nektarios the Monk, currently in Ms.7 LMCMB are the stichera of the Sunday gospels (the eothina); this cycle presents the same tempo characteristics and musical discourse as the Theotokia. The theme, however, is different, related to the Resurrection of the Lord and the moment when the myrrh-bearing women become aware of it. The version of the stichera of the Resurrection translated and adapted by Nektarios the Monk from Iakovos Protopsaltis has been brought back to the practice of the Orthodox church, both monastic and secular; they were published in the collection of Buchet muzical athonit. Cântările Utreniei [A musical collection of chants from the Mount Athos. Chants for the Matins] (2008, pp. 211-241).

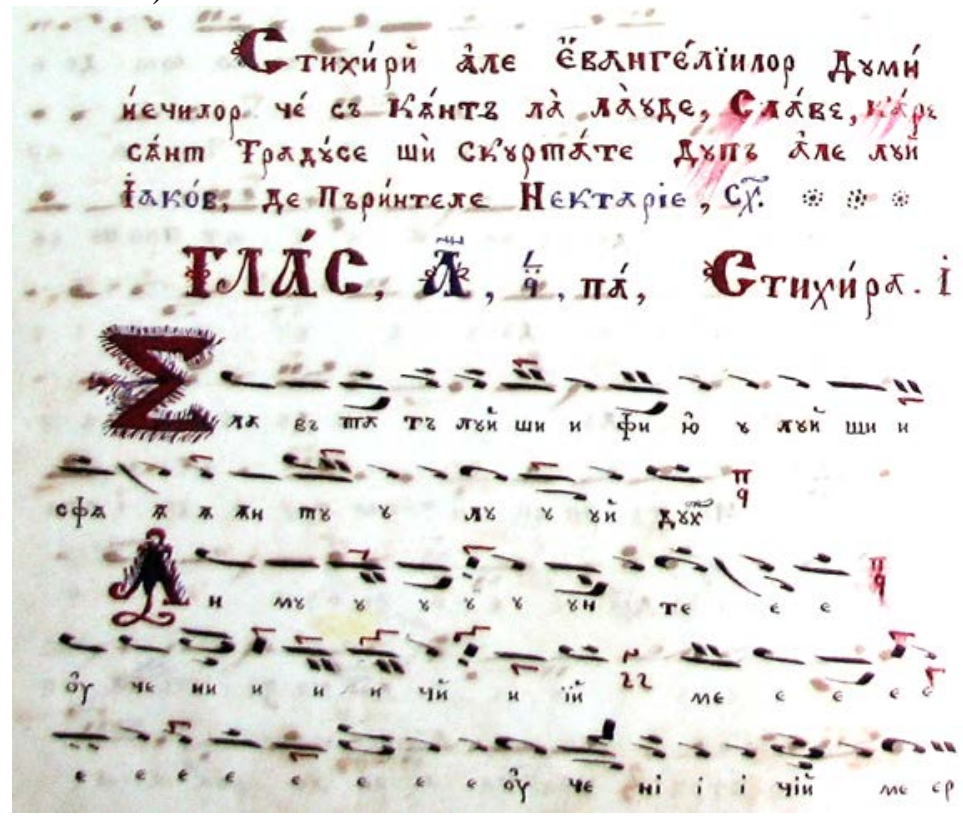

Fig. 2 l. $63^{v}$ Stichera of the Sunday gospels to sing during the Ainoi/Lauds [Eothina, o. n.], the doxastika translated and abbreviated according to Father Iakovos by Nektarios the Monk.

The 1st mode Pa The $1^{\text {st }}$ Stichera Glory... On the mountain the disciples 
Another composer mentioned in Ms. 7 LMCMB is Gregorios Protopsaltis (1778?-1821). He is known as one of the "three teachers", the founders of the Chrysantine Reform. Besides Chrysanthos of Madytos and Hourmouzios Hartophilakos (the Registrar), he taught at the Patriarchal School of Music (from 1815 to 1819). He held the positions of the conductor of the left choir members ("lampadarios") and then of protopsaltis of the Patriarchate of Constantinople. Through his music, both original pieces and transcriptions in the new notation of the opera of the great composers, he contributed to the implementation of the reform of Orthodox church music and of the modern, simplified musical notation. Below are some of his most outstanding traslations: The Kalophonic Heirmologion by Petros Bereketis, which he transcribed from the Koukouzelian notation (late medio-byzantine) into the modern Chrysantine notation; Anastasimatarion syntomon (the short version) by Petros Lampadarios, etc. (Apud Oxford Music online, Gregorios Protopsaltis) In terms of his original creations, I mention the series of axions (chants from the divine Liturgy, dedicated to the Mother of God) and the two series of great cherouvika, organized on modes. One of these series of "large" cherouvika ("large" in the sense that they are written in "extensive", papadic musical writing) are copied in Ms. 7 LMCMB, in the translation and musical adaptation of Nektarios the Monk (1804-1899), who was a Romanian composer and psaltes active in Holy Mount Athos.

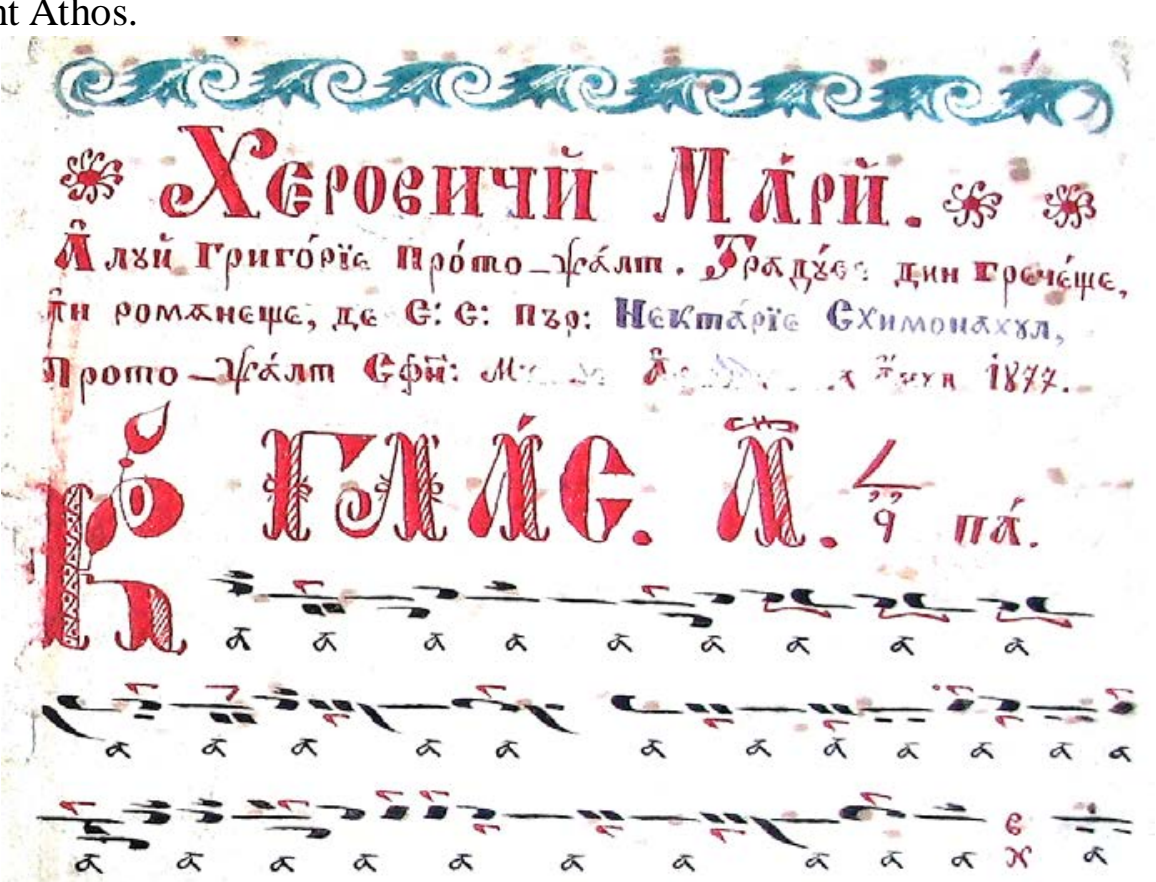

Fig. 3 1. 1 "Great Cherouvika by Gregorios Protopsaltis”. Translated from Greek into Romanian by S.S. F[ather] Nektarios the M[onk], protopsaltis [of] the Holy Mount Athos [around] the year 1877. Mode I Pa, Which onto the cherubs 
His biography and musical work were studied by Romanian Byzantinologists Sebastian Barbu-Bucur and Vasile Vasile, in studies, cataloguess and collections of repertoire pieces (Barbu-Bucur, 1998; 2000; Vasile, 2001, 2004). Famous singer, also known as "the nightingale of the Holy Mountain”, he was the founder of a genuine school of interpretation and psaltic composition. He enriched the church repertoire with many musical translations and adaptations from the Greek language, but also with inspired original creations, recorded in the Chrysantine analytical notation (detailed in terms of the ornaments).

Thus, as mentioned previously, he translated Doxastarion by Iakovos, as well as the collections of the Triodion, Pentikostarion and Sticherarion. He also adapted and composed cherouvika, axions on the eight modes, koinonika, antiphona, anixandaria, stichera, heirmoses, doxastika, polyeleoi, doxologies, Chants for the Lord's Funeral, The Service on the Celebration of the Icon of the Mother of God of Prodromos Hermitage, in other words, a large number of chants that cover the whole range of church repertoire (Barbu-Bucur, 1998, p. 24).

Researching the collections of the anthology Buchet muzical athonit for the Divine Liturgy (in two editions: 2000, 2009), I have discovered that the version of the Great Cherouvika by Gregorios Protopsaltis, adapted by Nektarios the Monk, has not yet been edited.

It is interesting that they are not included either in the significant collection by Nektarios Protopsaltes of the Holy Mount Athos - Chants of the Divine Liturgy, edited by the Byzantinologist Vasile Vasile, after the manuscripts from the various document funds located on the Holy Mountain. Therefore, Ms. 7 LMCMB, along with other manuscripts, such as for example Ms. 28 from the Library of the Prodromos Romanian Hermitage (LPRH) - Antologhion, l. 110v-131 (Vasile, 2008, p. 98) and Ms. 3049-3050 LPRH - Chants of the Liturgy, l. 31ㄴ-43 (Vasile, 2008, p. 242) represents an important documentary source so that the extensive Cherouvika by Gregorios Protopsaltis can be printed and made accessible to church singers and choirs in Romania.

An interesting presence in terms of the repertoire in Ms.7 LMCMB is also the service dedicated to the Miracle working Icon of the Virgin our Lady Mother of God of the Prodromos Hermitage composed by Nektarios Protopsaltis in 1863. 


\section{0.

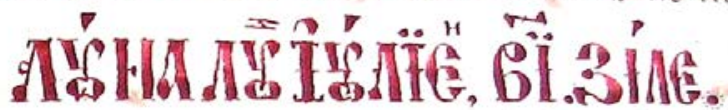

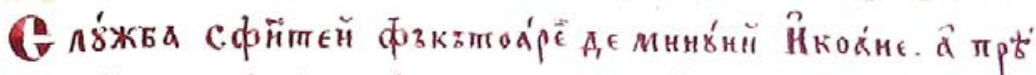

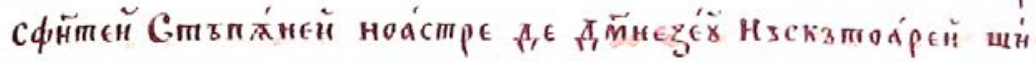

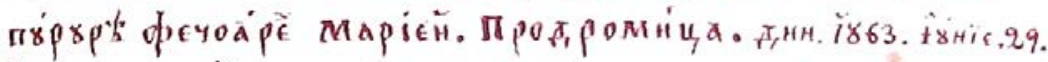

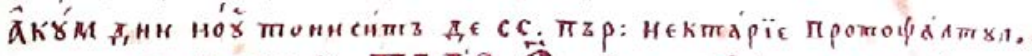

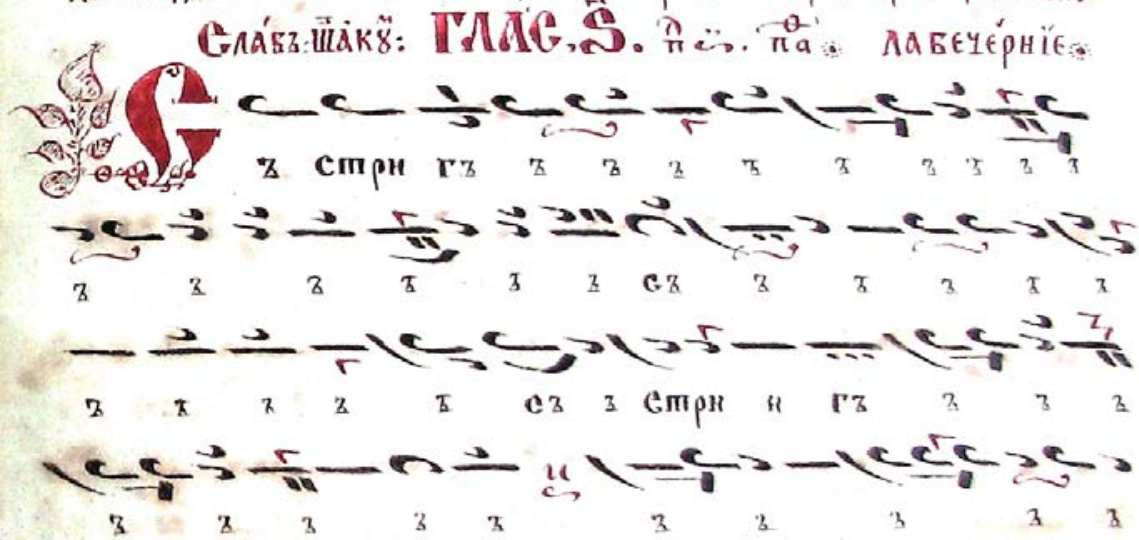

Fig. 4 l. 106 the Month of July in 25 days. The Service dedicated to the Holy Miracle-working icons of Virgin our Lady, Mother of God of the Prodromos Hermitage. Of 1863 June 29. Now again composed by H[is] H[oliness] F[ather] Nektarios Protopsaltes. Glory; Both now and ever.

The plagal of the $2^{\text {nd }}$ mode Pa At Vespers Let us call today with the sweet songs

Since the miracle working icon was located at great the Prodromos Hermitage, the service composed by Nektarios the monk dedicated to it is of importance especially for the Romanian monks on Mount Athos, but not only. On the one hand, some parts of the chants (different from those sections contained in Ms. 7 LMCMB) are noted in Ms. 1765 BSRP - Sticherarion, l. 48-58 (Vasile, 2008, p. 169), Ms. 1766 BSRP - Sticherarion, l. 101-122 (Vasile, 2008, p. 170), Ms. 3255 BSRP - Antologhion, l. 215는 227 (Vasile, 2008, p. 274), Ms. 3619 BSRP - Sticherarion, l. 203-224 (Vasile, 2008, p. 293) etc. On the other hand, we find the same parts of the chants as in Ms. 7 LMCMB also noted in Ms. 1772 BSRP - Antologhion, l. 218-229 (Vasile, 2008, p. 174) and probably also in other document funds on Mount Athos. The first recent full record of the service dedicated to the Icon of the Prodromos Hermitage is that performed at the Center for Byzantine Studies in Iasi, in 2002. At the end of Ms. 7 LMCMB, the leaves 106-110 includ a few musical parts of the service dedicated to the icon at Prodromos Hermitage, namely the chants of doxastikon type that complete the main parts of the vespers: a doxastikon in the plagal of the $2^{\text {nd }}$ 
mode Pa after the stichera Lord, unto You I have cried, a second one doxastikon in the $4^{\text {th }}$ mode $\mathrm{Pa}$ at the Lity service, and the third, in the $1^{\text {st }}$ mode $\mathrm{Pa}$, from Aposticha. The doxastika composed by Nektarios are ample, in the sticheraric musical notation and in medium movement, in a classic style, based on the traditional musical formulae ("theses"), specific of the mode used. Also, the leaves 111-111v also contain two versions of the troparion to the Icon of the Mother of God of the Prdromos Hermitage, both in mode I, the first in irmological notation and fast movement, for the end of Vespers, and the second, in a medium movement and sticheraric notation, for the Lity.

Another series of large cherouvika in Ms. 7 LMCMB, translated by Nektarios Protopsaltes, is that on leaves $33-47 \mathrm{v}$, belonging to the Greek composer and publisher Theodor Fokaefs (approx.1790-1851). He was a student of George of Crete and of teachers Gregorios Lampadarios and Hurmuz Hartofilax, at the third Music School of the Patriarchate of Constantinople (1815-1821). It is recognized as a Greek musician particularly active as a professor of church and secular music, psaltes, composer and editor of several collections containing the fundamental repertoire of the Chrysantine music. (Fokaefs, 1847-1848; 1851-1855). Some of his most famous creations are Anixandaria "the short version" and the psalm Happy is the man, both in the plagal of the mode IV, eight sets of Kekragaria chants (Lord, unto You I have cried) on modes, the polyelei Confess unto the Lord in mode IV leghetos and Good word in the mode of varis, two series of cherouvika on modes, for each week and holiday, in both "abbreviated" and "extensive" form, Sunday's koinonika in medium movement and "argo-syntomon" notation, koinonika for the great feasts, koinonika for the days of the week, koinonika for the Holy Thursday, koinonika for The Holy Saturday, etc. His work is considered innovative and different from that of the musicians and teachers of the Patriarchate because it introduces the influences of secular music, thus anticipating the trends of the second half of the 19th century (Hatzigiakoumis, Theodore Fokaefs). The extensive Cherouvika in Ms. 7 LMCMB are published neither in the collection Buchet muzical athonit. Dumnezeiasca Liturghie [A Musical Anthology. The Divine Liturgy] (Lacoschitiotul, 2009), nor in the volume Nektarios Protopsaltis at the Holy Mount Athos - Cântări ale Sfintei Liturghii/ Chants of the divine Liturgy (Vasile, 2004), possibly due to its ample. As a rule, the extensive cherouvika were performed during the festive services, for example, at feasts of the titular saint or when the archpriest visited. The initial part of the extensive cherouvikon (for the holidays) and that for Sunday regular "ordinary" service, in the $1^{\text {st }}$ mode Pa, by Theodor Fokaefs, translated by Nektarios Protopsaltis, is offered for comparison: 


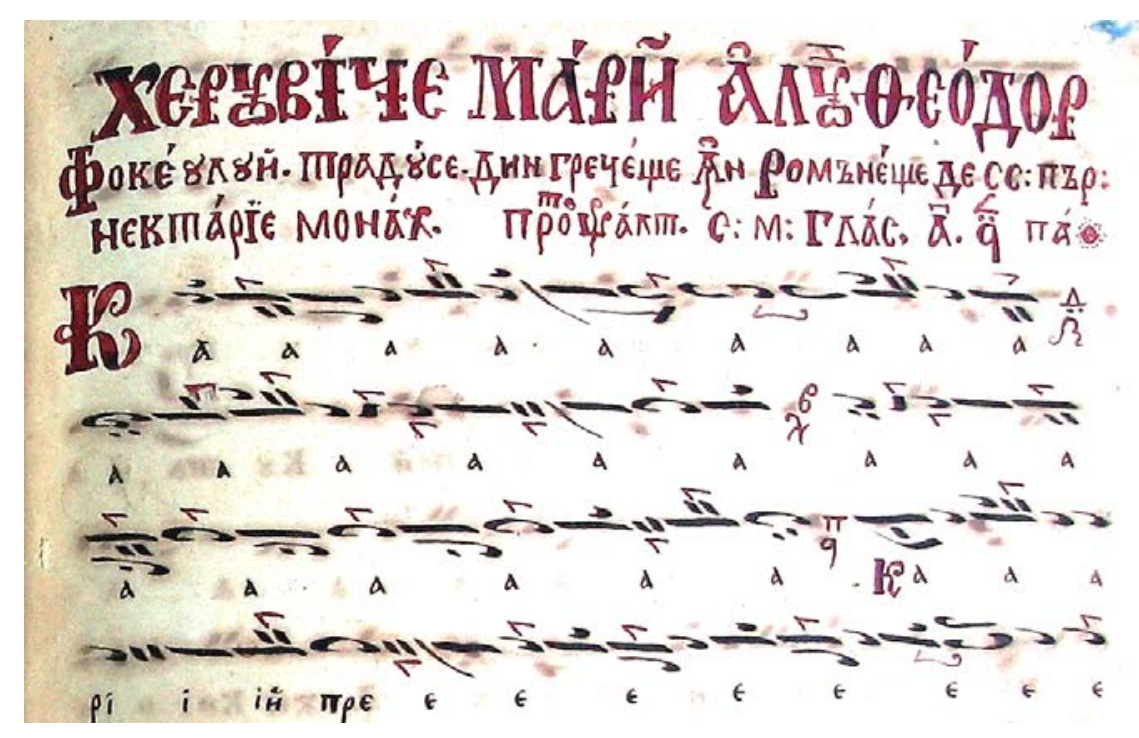

Fig. 5 Ms. 7 LMCMB 1. 33 Great Cherouvikon by Theodore Fokaefs translated from Greek into Romanian by H. H. Fat[her] Nektarios [the Monk], Protopsaltes [of the] H[oly] M[ount] The $1^{\text {st }}$ mode Pa, Which onto the cherubs

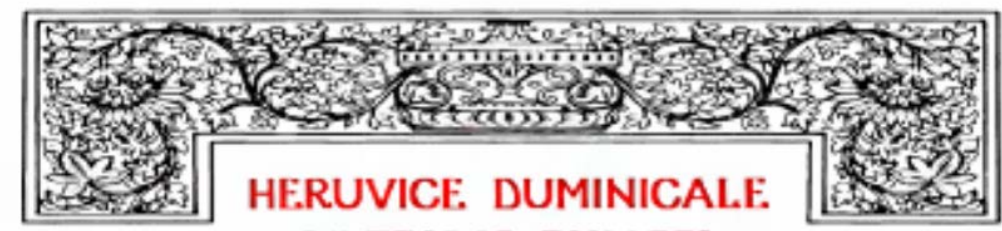

DE TEODOR FOKAEFS

TRADUSE DE SCHIM. NECTARIE.

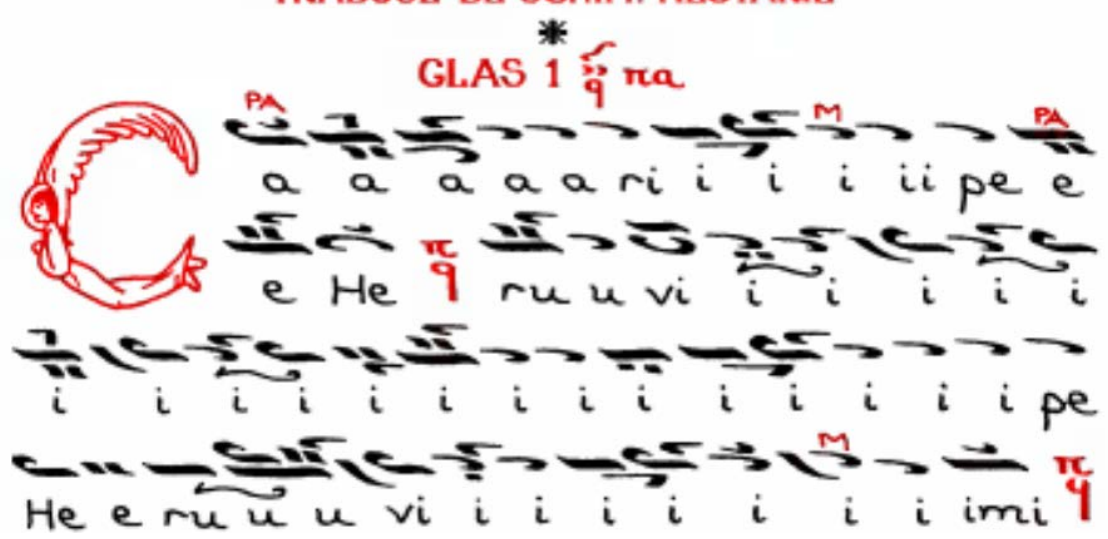

Fig. 6 Sunday Cherouvikon by Theodor Fokaefs, mode I Pa Which onto the cherubim (Lacoschitiotul, 2009, p. 143)

The difference in writing in terms of the text-music relation can be easily seen: if in the first version, the syllable "Ca" in the word "Carii" (= Which) 
corresponds to 46 prime time units ${ }^{2}$, in the second version of the Sunday's cherouvikon, the same syllable corresponds to only 10 prime time units. Therefore, the time it takes for the the first extended cherouvikon to perform is, obviously, much more extensive than the second, so it is more appropriate to interpret on a festive occasion. Also, the melodic formulae of the first version are more complex, use more of temporal augmentative and diminutive temporal signs, are more difficult to perform and require experienced psaltes/ singers in comparison with the second version, where the "theses" are easier to follow and perform. Beside the manuscripts Ms. 28 LPRH - Antologhion, 1. 45-63v (Vasile, 2008, p. 98), Ms. 1678 LPRH - Antologhion, l. 40-54v (Vasile, 2008, pp. 119-120), Ms. 1708 LPRH - Chants of the Liturgy, l. 1-36 (Vasile, 2008, p. 131), Ms. 30493050 LPRH - Chants of the Liturgy, l. 20-31v (Vasile, 2008, p. 242) etc., Ms.7 LMCMB can serve as a source for the editing in Romanian of the extended Cherouvika by Theodor Fokaefs.

Finally, a more special piece is in the manuscript described on leaves 88 to 90, the doxastikon from Aposticha of the Great Wednesday, Lord, the fallen woman, mode VIII, in the "abbreviated" version by Nektarios Frimu (†1856). Born in Husi, like Nektarios Protopsaltes of the Holy Mountain, whom he was even mistaken for at first, Nektarios Frimu worked at the Neamt Monastery (where he was hierodeacon) and then in Iasi. He was a gifted psaltes and composer, a fine connoisseur of both ecclesiastical and secular music. For his outstanding merits in the area of church music, he was awarded the honorary title of "hierarch of Tripoleos". He is the author of the volumes Antologhie sau floarealegire/ An Anthology or miscellany - Volume III (1840), containing chants of the Divine Liturgy and volume I and II - chants from Vespers and Matins (1846). These are among the first works of this kind in the Romanian language, and in Chrysantine notation, which was particularly popular in the second half of the 19th century. Many of Nektarios Frimu's hymns in his printed volumes were widely circulated in the manuscripts made in Northern and Southern Moldavia and Tara Românească until towards the end of the 19th century; after that, they were gradually forgotten (Bucescu, 2009, II, pp. 8, 149).

The Doxastikon of the Holy Wednesday, Lord, the fallen woman is a well known chant performed during the Passion Week; it is very old, generally attributed to Byzantine Hymn composer Cassia the Nun (9th century). In the Romanian psaltic literature of the 19th century, several variations of this doxastikon are known, of which the most widely known, currently, is that by Dimitrie Suceveanu, in sticheraric writing and moderate movement, included in volume III of the Idiomela edited in 1857 in the printing press of the Neamt Monastery and reissued in Iasi in 1997. There are, however, other, earlier,

\footnotetext{
2 The prime time unit ("hronos protos") represents the standard time unit for psaltic music, the equivalent of the quarter in the linear music.
} 
versions of this doxastikon, such as those translated and adapted by Visarion Protopsaltis (19th century), a brilliant representative of the Musical School at the Neamt Monastery, which flourished at the end of the 18th century and in the first half of the 19th century. His creation is ample and includes the Sticherarion, the Heirmologion, Chants of the Triodion, Pentikostarion, chants for the Divine Liturgy, Vespers and Matins a. o. (Vasile, 2005, pp. XXI-XXIV). Only a relative small number of these chants have been published, namely those of the period of the Triodion (Balan, 2005), where the doxastikon Lord, the fallen woman, in the plagal of the $4^{\text {th }}$ mode $\mathrm{Ni}$, is also included; it occurs in 3 ample versions, translated and adapted for music by Visarion Protopsaltes after the Greek "classical" musical fashion, such as that of Petros Lampadarios. The latter variant presents similarities only in the initial part, with the respective doxastikon present in Ms. 7 LMCMB, abbreviated by Nektarios Frimu, who does not mention the source which was "abridged". I mention that the doxastikon Lord, the fallen woman adapted by Nektarios Frimu is also contained in Ms. 20 BMMB at leaves 35-37. Gheorghe Ionescu, too, found it in Ms. 31/49 BMMB, leaves 114-116v, and also in Ms. Romanian 28944 from the National Library of Romania, on page 82, where it is indicated, this time, that Macarie Ieremonahul is the source after which it was "abbreviated" (Ionescu, 2002, p. 155). The initial sections of the respective doxastikon are further presented in comparison, in the two versions mentioned above, first by Nektarios Frimu, and second, by Petros Lampadarios.

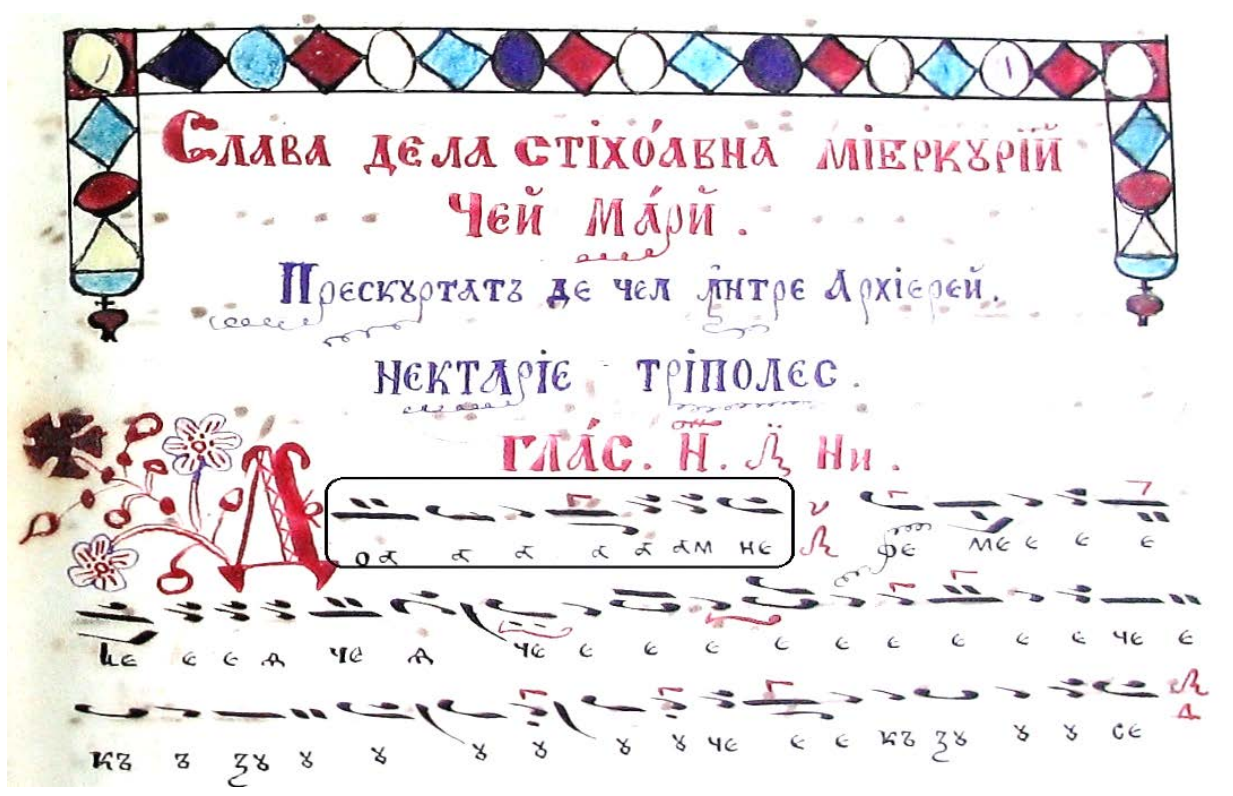

Fig. 7 L. 88 Doxastikon from Aposticha of the Great Wednesday abridged by one among bishops Nektarios Tripoleos. The plagal of the $4^{\text {th }}$ mode Ni Lord, the fallen woman. 


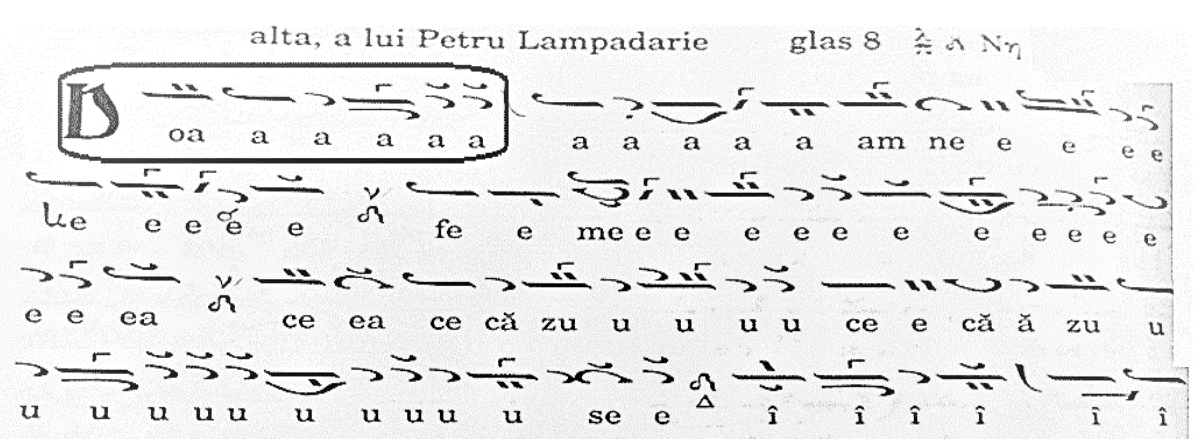

Fig. 8 Another [doxastikon], by Peter Lampadarios, the plagal of the $4^{\text {th }}$ mode $\mathrm{Ni}$ Lord, the fallen woman (Balan, 2005, p. 286)

The melodic formula of the initial section in both chants is identical, but the musical discourse differs remarkably: in the second version, by Petros Lampadarios, translated by Visarion Protopsaltis, the melismas are much more ample, while in Nektarios Frimu's version, the script is "argo-syntomon", more restricted in terms of melismas. The doxastika Lord, the fallen woman, mode VIII by Nektarios Frimu is a novel unique valuable creation which deserves to be published. There are a few other chants from the Lent period, belonging to the composer mentioned above, unpublished in his volumes of Antology and relatively recently discovered: the Doxastikon Woe is me, my blackened soul, the plagal of the $4^{\text {th }}$ mode $\mathrm{Ni}$, of the Sunday of the Terrible Judgment (on Shrove Tuesday before Lent) and the sticheron of the Good Friday, "after surrounding the church with the Epitaphios", Come praise Joseph, the plagal of the $1^{\text {st }}$ mode $\mathrm{Pa}$, in Ms. 1546, chrysantine Antologhion, from the National Archives of Iaşi (Bucescu, 2009, II, p. 165). These two valuable pieces of music have recently been published in double notation, psaltic and linear (Danila, 2013, pp. 159-170). I will also include in the appendix the integral score of the doxastikon Lord, the fallen woman by Nektarios Frimu ${ }^{3}$.

\section{Conclusions}

3.1. Ms.7 LMCMB is a Chrysantine anthologion, written entirely in Romanian with cyrillic transitional alphabet, no place mentioned, by an unknown copyist, approximate dated in the 8-9th decades of the 19th century.

3.2. The main author of the chants is Nektarios Protopsaltis of the Holy Mountain, present especially as the "translator" into Romanian of some of the creations by established Greek composers: Iakovos Protopsaltis, Gregorios Protopsaltis, Theodor Fokaefs.

3.3. The second important Romanian composer mentioned in Ms. 7 LMCMB is

3 Special thanks to Stefan Ilie Graur, second year student under the Religious Music Specialization at the "George Enescu" National University of Arts (Iasi) for editing the score. 
Nektarios Frimu, a native of Husi, awarded with the honorary title of "abbot of Tripoleos", the author of the doxastikon Lord, the fallen woman, in the plagal of the $4^{\text {th }}$ mode $\mathrm{Ni}$, which he abridged. This doxastikon was not printed in his volumes of Anthology.

3.4. Ms. 7 Antologhion is a valuable codex in the "Dumitru Staniloae" Ecumenical Library of the Metropolitan Church of Moldavia and Bukovina, Iasi (Romania), since, along with other manuscripts from the libraries of the monasteries of the Holy Mount Athos, it represents an important documentary source which can assist publishing chants yet unpublished in the contemporary Romanian Byzantine literature (the extended Cherouvika by Gregorios Protopsaltis and Theodore Fokaefs translated by Nektarios Protopsaltes and the doxastikon Lord, the fallen woman adapted by Nektarios Frimu).

\section{References}

Barbu-Bucur, S. (1998). Nectarie Protopsaltul Sfântului Munte - la 100 de ani de la moartea lui [Nektarios Protopsaltis of the Holy Mount - at 100 years from his death]. In Acta Musicae Byzantinae, II, 16-35. Iași: Centrul de Studii Bizantine.

Barbu-Bucur, S. (2000). Manuscrise muzicale româneşti de la Muntele Athos [Romanian musical manuscripts from Mount Athos]. București: Editura Muzicală.

Barnea, A (2009). Muzica bisericească în Moldova secolului al XIX-lea [Ecclesiasical Music in Moldavia,19 ${ }^{\text {th }}$ century]. Iași: Editura „Sf. Mina”.

Bălan, F. (2005). Antologhion paisian. Tomul I. Perioada Triodului [Paisian Anthologion. Tome I. The Triodion Period]. București: Editura Sophia.

Bucescu, F. (2009). Cântarea psaltică în manuscrisele moldovenești din secolul XIX. Ghidul manuscriselor psaltice - Moldova, sec. XIX, [The psaltic chant in the moldavian manuscripts fo $19^{\text {th }}$ century. The Guide of the psaltic manuscripts Moldavia, $19^{\text {th }}$ century], I, II. Iași: Artes.

Bucescu, F. \& Catrina, C. \& Barnea, A. et al. (2010). Catalogul manuscriselor de muzică sacră din Moldova - sec. XI-XX [The Catalogue of sacred music Manuscripts of Modavia $-11^{\text {th }}-20^{\text {th }}$ century], I. Iaşi: Artes.

Dănilă, I. Z. (2013). Studiul manuscriselor muzicale psaltice din Arhivele Naționale din Iași [The Study of the psaltic music manuscripts of National Archives of Iasi]. In Studii de sinteză: 2012-2013 [Synthetic Studies: 2012-2013], II (pp. 179-170). București: Editura Universității Naționale de Muzică București.

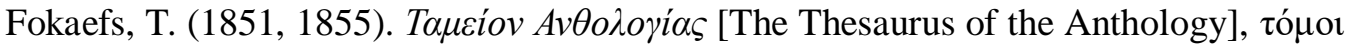
$\mathrm{A}^{\prime}-\Gamma^{\prime} . \mathrm{K} \omega v \sigma \tau \alpha \nu \tau \iota v o v ́ \pi \mathrm{o} \lambda \eta$.

Frimu, N. (1840). Antologhie sau floarealegire [Anthology or miscellany], III. Tipografia Mănăstirii Neamț.

Frimu, N. (1846). Antologhie sau floarealegire [Anthology or miscellany], I, II. Tipografia Mănăstirii Neamț. 


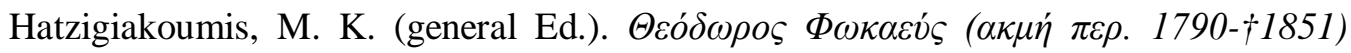
[Theodor Fokaefs $(\sim 1790-\dagger 1851)]$, retrieved from http://www.e-

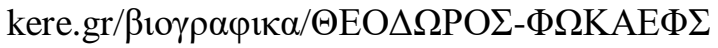

Ionescu, Gh. C. (2002). Muzica bizantină în România. Dicționar cronologic [Byzantine Music in Romania. Chronologic Dictionary]. București: Editura Sagittarius.

Lacoschitiotul, I. (2009). Buchet muzical athonit - Dumnezeiasca Liturghie [A musical collection of chants from the Mount Athos - The Divine Liturgy], 1. București: Evanghelismos.

Suceveanu, D. (1997). Idiomelar [Idiomelarion], III. Barbu-Bucur, S. (Ed.), Iași: Editura „Trinitas” a Mitropoliei Moldovei și Bucovinei.

Vasile, V. (2001). Școala lui Nectarie Vlahul [The School of Nektarios Vlachos]. In Acta Musicae Byzantinaei, III, 113-121. Iași: Centrul de Studii Bizantine.

Vasile, V. (2002). Nectarie Frimu - figură reprezentativă a muzicii psaltice românești [Nektarios Frimu - representative figure of the Romanian psaltic music]. In Acta Musicae Byzantinae, IV, 157-179. Iași: Centrul de Studii Bizantine.

Vasile, V. (2004). Studiu introductiv [Introductory Study]. In Vasile, V. (Ed.), Nectarie Protopsaltul Sfântului Munte - Cântări ale Sfintei Liturghii [Nektarios Protopsaltis at the Holy Mount Athos - Chants of the Holy Liturgy] (pp. XI-CXXX). București: Evanghelismos.

Vasile, V. (Ed.), 2004. Nectarie Protopsaltul Sfântului Munte Athos - Cântări ale Sfintei Liturghii [Nektarios Protopsaltis at the Holy Mount Athos - Chants of the Holy Liturgy]. București: Evanghelismos.

Vasile, V. (2005). Școala paisiană de muzică bizantină. Ieromonahul Visarion Protopsaltul [The Paisian School of Byzantine Music]. In Bălan, F. (Ed.). Antologhion paisian. I. Perioada Triodului (pp. V-XXIX). București: Editura Sofia.

Vasile, V. (2007). Tezaur muzical românesc din Muntele Athos [Romanian musical Thesaurus form Mount Athos], I. București: Editura Muzicală.

Vasile, V. (2008). Tezaur muzical românesc din Muntele Athos [Romanian musical Thesaurus form Mount Athos], II. București: Editura Muzicală.

*** (2000). Buchet muzical athonit. Cântările Sfintei Liturghii [A musical collection of chants from the Mount Athos. The chants of the Holy Liturgy], 1. Sfântul Munte Athos: Chilia „Buna Vestire” - Schitul „Sf. Dimitrie” - Lacu.

*** (2008). Buchet muzical athonit. Cântările Utreniei [A musical collection of chants from the Mount Athos. The chants of the Matins]. București: Evanghelismos.

http://www.oxfordmusiconline.com/search?q=Jakobos+protopsaltes\&searchBtn=Searc h\&isQuickSearch=true

http://www.oxfordmusiconline.com/search?q=Gregorios+Protopsaltes\&searchBtn=Sea rch\&isQuickSearch=true 


\section{Appendix}

\section{Catalogue Ms. 7 LMCMB of the Manuscript inventory number 7 of "Dumitru Staniloae" Ecumenical Library of the Metropolitan Church of Moldavia and Bukovina ${ }^{4}$ (Ms. 7 LMCMB) \\ The type of collection: Psaltic Antologhion}

\section{Summary box}

“Dumitru Stăniloae” Ecumenical Library of the Metropolitan Church of Moldavia and Bukovina in Iasi, Ms. 7 (old inventory number 550). No front page. Language used: Romanian. Alphabet: transitional cyrillic. Copyist: unknown. Musical semiography: Chrysantine notation. Date: 8-9 decades of the 19th century. No place mentioned. Preliminaries: priest Fl. Bucescu, Cântarea psaltică în manuscrisele moldovenești din secolul XIX. Ghidul manuscriselor psaltice - Moldova, sec. XIX [Psaltic Chant in the Moldavian manuscripts of 19th century. The Guide to Psaltic Manuscripts - Moldavia, 19th century], Editura Artes, Iași, 2009, vol. I, p. 28, vol. II, pp. 108, 126; priest Al. Barnea, Muzica bisericească în Moldova secolului al XIX-lea [Church Music in Moldavia in the $19^{\text {th }}$ century], Editura „Sf. Mina”, Iaşi, 2009.

\section{Codicological description}

Size: $19.8 x 16.7$ x1.7 cm. Number of leaves: 112 . Black cardboard cover with cloth spine and corners. Fairly good state of preservation. Torn cloth on the spine, cloth on the edges is frayed, leaves with foxing stains. Has not been restored. It is located in the storeroom of the "Dumitru Stăniloae" Ecumenical Library, the historical department ${ }^{5}$. Numbering of a later period, in pencil, on the upper right corner. I discovered an numbering error, 2 leaves are numbered with the number 87, therefore Ms. 7 contains 112 leaves, not 111 (as is noted in the sheet accompanying the manuscript). Neat, elegant handwriting by two professional amanuenses. Black ink is used for the vocal neumes, the temporal augmentative signs, the psifiston, varia, omalon, antichenoma consonant signs, and red ink for initials, capital letters, ftora, martiria, diminutive temporal signs, the consonant eteron sign. Some initial capital letters are decorated with floral motifs. Beautifully artfully frontispieces decorated with geometric and plant motifs; red and black colours are prevalent. The only frontispiece in the manuscript decorated in dark red, yellow, indigo, light blue (probably in crayon) appears on leaf 87.

\footnotetext{
${ }^{4}$ The cataloging criteria used for the present study follows that in the volume: Bucescu, F. \& Catrina, C. \& Barnea, A. et al. (2010). Catalogul manuscriselor de muzică sacră din Moldovasec. XI-XX [The Catalogue of sacred music Manuscripts of Modavia $-11^{\text {th }}-20^{\text {th }}$ century], I. Iaşi: Artes.

${ }^{5}$ According to the description by expert restorer Mihaela Puiu in December 2009.
} 


\section{Date and Location}

Since leaf 1 , face of the first chapter bears the note 1877, the year when Hermit Nektarios Protopsaltes translated the Great Cherouvika by Gregorios Protopsaltis, while on leaf $76^{\mathrm{v}}$ the date " 1882 January 12 th" is written, Ms.7 is likely to be from the decades 8-9 of the 19th century. Also, given that most songs in the manuscript belong to Nektarios Protopsaltis at the Holy Mountain as a translator and composer, Byzantinologist Priest Florin Bucescu hypothesizes that this manuscript is likely to have been made at the Holy Mountain, perhaps even by a follower of the protopsaltes (Bucescu, 2009, II, pp. 108, 126).

\section{Musical-liturgical content}

leaf (l.) 1 Gregory Protopsaltis' GREAT CHEROUVIKA. TRANSLATED FROM GREEK INTO ROMANIAN BY H.[IS] H.[OLINESS] FATHER NEKTARIOS THE ANCHORET, PROTOPSALTES [OF] the HOLY MOUNTAIN ATHOS 1877 [Sunday Cherouvika, in "large” style ("arga”), on the eight modes, Which to the cherubim, our note - o. n.] The $1^{\text {st }}$ mode $\mathrm{Pa}$ Which to the cherubim; $1.4^{\mathrm{v}}$ The $3^{\text {rd }}$ mode Ga; $1.8 \mathrm{v}$ The $4^{\text {th }}$ mode Di; 1.12 The plagal of the $4^{\text {th }}$ mode; 1.16 The $2^{\text {nd }}$ mode [modulated in the plagal of the $2^{\text {nd }}$, 0 . n.] Pa; 1 . 20 The plagal of the $1^{\text {st }}$ mode Pa; 1 . 24 The plagal of the $2^{\text {nd }}$ mode Pa; 1 . 28 The plagal of the $3^{\text {rd }}$ mode Zo.

l. 33 THE GREAT CHEROUVIKA BY THEODORE FOKAEFS TRANSLATED FROM GREEK INTO ROMANIAN BY H. H. FATHER NEKTARIOS PROTOPSALTIS, MONK AT S[AINT] M[OUNT] [extended Cherouvika, on modes, Which onto the cherubim, o. n.], The $1^{\text {st }}$ mode $\mathrm{Pa}$, Which onto the cherubim; l. 35 The $2^{\text {nd }}$ mode $\mathrm{Di}$; 1.37 The $3^{\text {rd }}$ mode Ga; 1.39 The $4^{\text {th }}$ mode Di; l. 41 The plagal of the $1^{\text {st }}$ mode Pa; l. 43 The plagal of the $2^{\text {nd }}$ mode Pa; l. 45 The plagal of the $3^{\text {rd }}$ mode Zo; 1.47 The plagal of the $4^{\text {th }}$ mode Ni.

l. 48 The GLORIES AND the THEOTOKIA BY IAKOVOS PR(OTO)PS(ALTIS) TRANSLATED BY H. H. NIKTARIOS PSALTES (of) S. M. ATHOS. The $1^{\text {st }}$ mode Pa Glory... Both now and ever... Onto which is the glory of the world; 1.51 The $2^{\text {nd }}$ mode Di Glory... Both now and ever... The shadow of the law passed away; 1. 52 $2^{\mathrm{v}}$ The $3^{\text {rd }}$ mode Ga Glory ... Both now and ever... How can we not marvel; $1.54^{\mathrm{v}}$ The $4^{\text {th }}$ mode Pa Glory... Both now and ever... The Prophet David; 1. 56v The plagal of the $1^{\text {st }}$ mode Pa Glory ... Both now and ever... In the Red Sea; 1. 58 ${ }^{\mathrm{v}}$ The plagal of the $2^{\text {nd }}$ mode Pa Glory... Both now and ever... Who will not call you blessed; 1.60 The plagal of the $3^{\text {rd }}$ mode Ga Glory... Both now and ever... Mother you were revealed; 1. 62 The plagal of the $4^{\text {th }}$ mode Ni Glory... Both now and ever... Lord of Heavens.

1. $63^{\mathrm{v}}$ THE STICHERA OF the SUNDAY GOSPELS TO SING ON THE AINOI, DOXASTIKA [EOTHINA, o. n.] WICH ARE TRANSLATED AND ABBREVIATED ACCORDING TO THE VERSION BY IAKOVOS BY 
FATHER NEKTARIOS [the] A[nchoret]. The $1^{\text {st }}$ mode I Pa, the $1^{\text {st }}$ Stichera [eothina, o. n.] Glory... The disciples hastened to the mountain; $1.64^{\mathrm{v}}$ The 2nd Mode $\mathrm{Di}$, the $2^{\text {nd }}$ Stichera Glory... The women with their ointments went with Mary to the tomb; 1. 66 The 3rd mode Ga, the $3^{\text {rd }}$ Stichera Glory... Mary Magdalene; 1.67 The $4^{\text {th }}$ mode Pa the $4^{\text {th }}$ Stichera Glory ... It was early dawn; l. $68^{\mathrm{v}}$ The plagal of the 1 st mode $\mathrm{Pa}$, the $5^{\text {th }}$ Stichera Glory... Oh, too wise Thy judgments; 1 . 70 The plagal of the $2^{\text {nd }}$ mode Pa, the $6^{\text {th }}$ Stichera Glory... Thou Christ are the true peace; $1.71^{\mathrm{v}}$ The plagal of the 3rd mode Zo, the $7^{\text {th }}$ Stichera Glory... Behold it is early and still dark; l. The plagal of the $4^{\text {th }}$ mode Ni, the $8^{\text {th }}$ Stichera Glory... Not in vain were the tears of Mary; $1.75^{\mathrm{v}}$ The plagal of the $4^{\text {th }}$ mode $\mathrm{Pa}$, the $9^{\text {th }}$ Stichera Now in these last times; $1.74^{\mathrm{v}}$ The plagal of the $2^{\text {nd }}$ mode $\mathrm{Pa}$, the $10^{\text {th }}$ Stichera After the descent into hell.

1. 77 The AKATHIST SERVICE The plagal of the 4th mode Ni Our God is the Lord; 1.78 Another [troparion], short, the plagal of the $4^{\text {th }}$ mode Ga like from Ni, God is the Lord; Another similar [troparion], the plagal of the $4^{\text {th }}$ mode $\mathrm{Ni}$, God is the Lord; $1.78^{\mathrm{v}}$ [the plagal of the $4^{\text {th }}$ mode, o. n.] Ni The mysterious Commandment [in "large" style, o. n.]; l. 79v Another shorter one [the plagal of the $4^{\text {th }}$ mode] Ni The mysterious Commandment; $1.79^{\mathrm{v}}$ Kontakion of Our Lady the Protectress, the plagal of the $4^{\text {th }}$ mode Ni Our Lady the Protectress [in "large" style, o. n.]; l. 82v Another [kontakion, o. n.], shorter, by Petros Bereketis, The plagal of the $4^{\text {th }}$ mode Ni Our Lady the Protectress.

1. 84 DURING THE HOLY AND GREAT WEEK of the PASSIONS the plagal of the $4^{\text {th }}$ mode Ni Alleluia... Behold the bridegroom [in "large" style, 0. n.]; l. $84^{\mathrm{v}}$ "Syndoma" [abbreviated, o. n.] The plagal of the $4^{\text {th }}$ mode Ga as from Ni Alleluia... Behold the bridegroom; l. 86 Another [troparion], shorter, as from Ga Behold the bridegroom; 1. 86 ${ }^{\mathrm{v}}$ On the Holy and Great Thursday. The plagal of the $4^{\text {th }}$ mode $\mathrm{Ga}$ as from Ni When all the blessed disciples; $1.87^{\mathrm{V}}$ Another shorter one $\mathrm{Ga}$ as from Ni When all the blessed disciples.

1. 88 The Doxastikon from Aposticha of the Great Wednesday abridged by one among bishops Nektarios Tripoleos. The plagal of the $4^{\text {th }}$ mode Ni Lord, the fallen woman.

l. 91-97 Polyeleos of the Holy Mother of God composed in Greek by Theodor Fokaefs, translated by His Holiness Father Nektarios Protopsaltis of the Holy Mountain in Romanian Monastery of S(aint) John the Baptist 1874 November Mode VII Zo Good word.

1. 98 Antiphon Legetos mode Vu From my youth;

l. 100 Happy is the man by Theodor Fokaefs translated into Romanian by S. S. F(ather) Nektarios Protopsaltes, Legetos mode Vu in 1880 Happy is the man;

l. 106 THE MONTH OF JULY IN 25 DAYS THE SERVICE OF THE HOLY MIRACLE-WORKING ICON OF OUR LADY, MOTHER OF GOD AND EVER-VIRGIN MARY OF PRODROMOS. OF 29 JUNE 1864. NOW AGAIN COMPOSED BY H. H. F. NEKTARIOS PROTOPSALTIS. Glory... 
Both now and ever.... The plagal of the $2^{\text {nd }}$ mode Pa At Vespers Let us call today with the sweet songs; l. 108 ${ }^{\mathrm{v}}$ Glory... Both now and ever.... Glas IV Pa The miracle of miracles too glorious; 1. 110 At the Aposticha Glory... Both now and ever.... The plagal of $1^{\text {st }}$ mode Pa On the light carrying cloud; 1.112 The troparion The $1^{\text {st }}$ mode Pa Oh, Virgin Theotokos, your holy and divine icon; 1. 112v The Troparion at Lity The 1st mode Pa Oh, Virgin Theotokos, your holy and divine icon.

\section{The list of recorded authors and translators}

Gregorios Protopsaltis, Theodor Fokaefs, Iakovos Protopsaltis, Nektarios the Anchoret, Nektarios Tripoleos.

\section{Complementary elements. Extra-musical notes:}

On the back overleaf I: the note "My books I.V. Erbiceanu"; leaf $76^{\mathrm{v}}$ : “1882. January 12”. 
II The score of Doxastikon Lord, the Fallen Woman abridged by Nektarios Frimu

\section{Slava dela Stihoavna Miercurii \\ Cei Mari}

Prescurtată de cel între Arhierei

Nectarie Tripoles (Ms. 7 BMMB)

$$
\text { Glas } \frac{\lambda}{\pi} \Delta^{\prime} \text {. }
$$

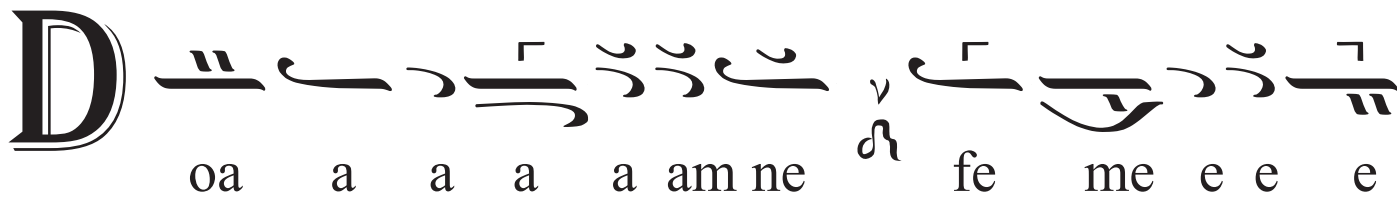

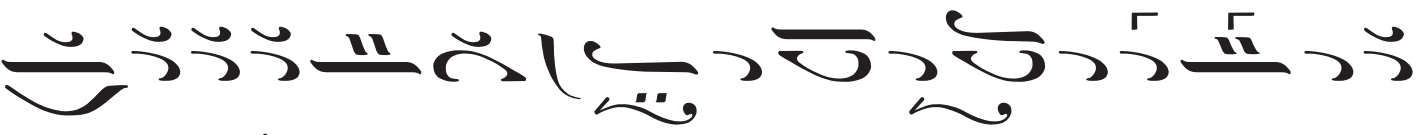

e e e ia ce ea ce e e e e e e e e e

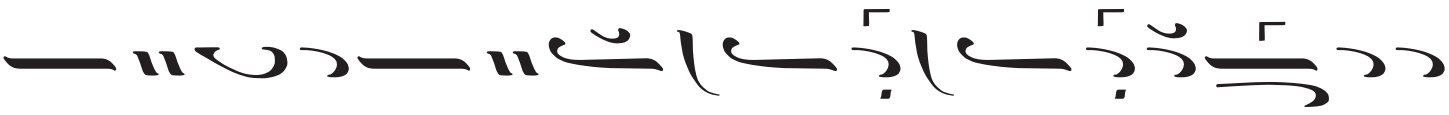

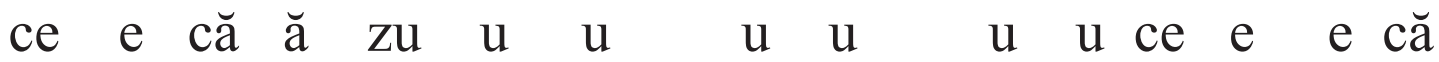

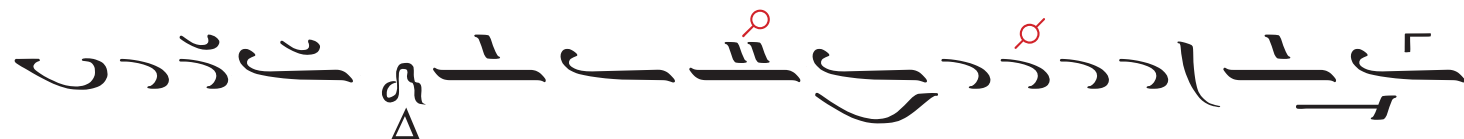

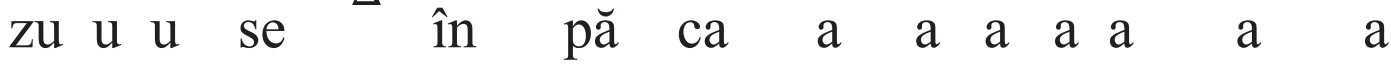

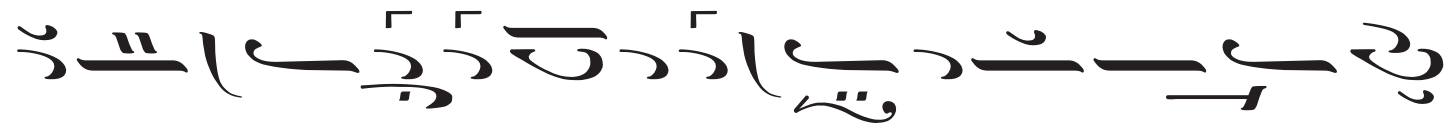

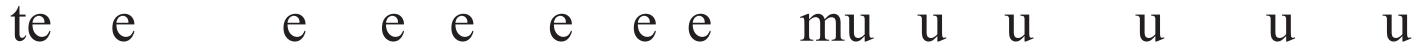

s几l-r în pă $\breve{a} \quad c a \quad a \quad a \quad$ te $\quad m u \quad c \quad u \quad u$

( > ' u u ul te $e^{\Delta} \operatorname{sim}$ ți ind dum ne $e$ ze e 


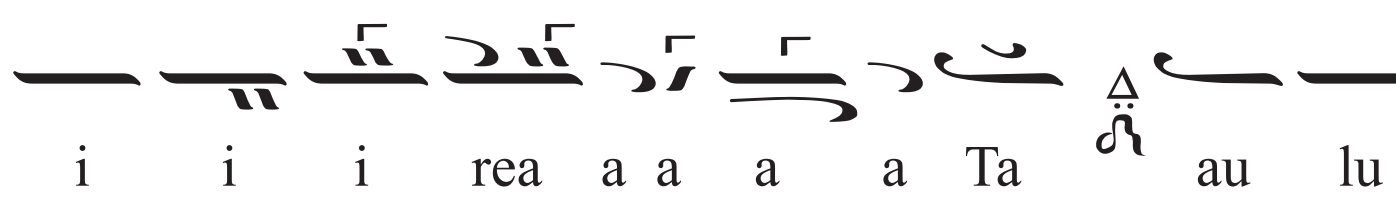

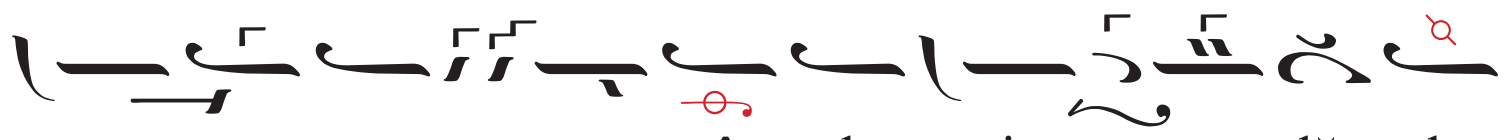

a a a a a at rân du ia a a lă de

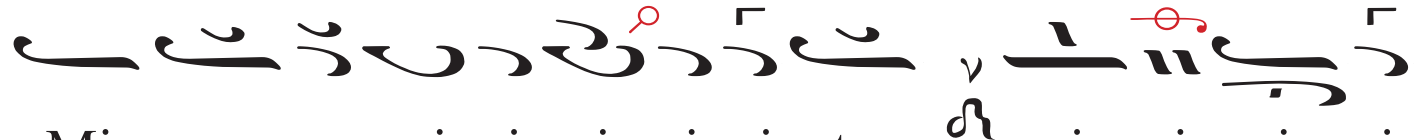

Mi ro no si $i$ i $i$ i țe ô și $i$ i $i$

(⿻上丨

i i i tâ şi $i$ tâ ângu $u$ u $\quad$ i i

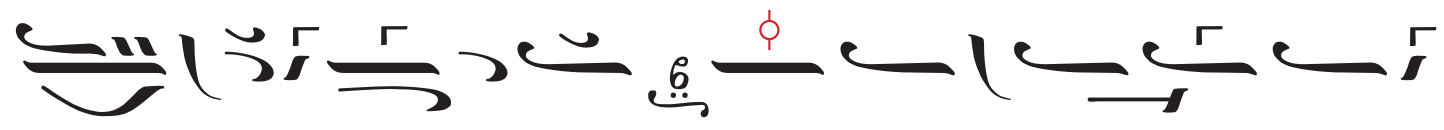

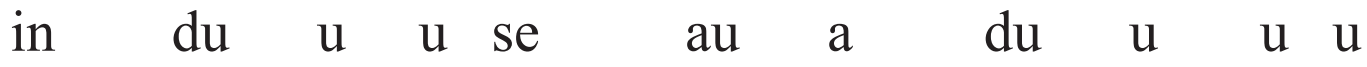

>는

us Ţi e e e e e mir mai 'na $i$ i in te de

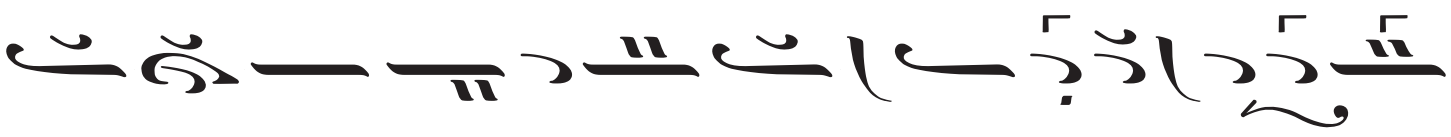

în gro pa a a a ${ }^{\text {a }}$ rea a a de e e

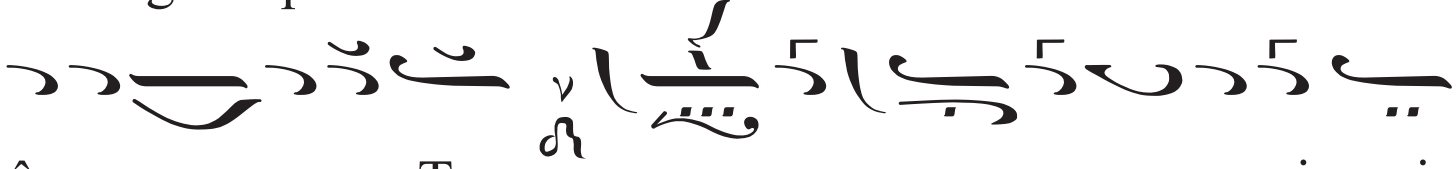

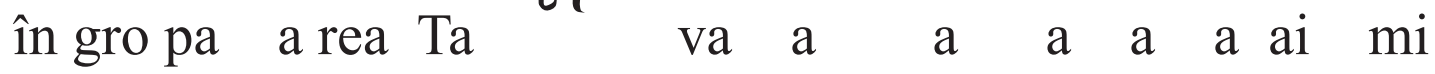
l冖 va ai mi i i e e zi câ â â

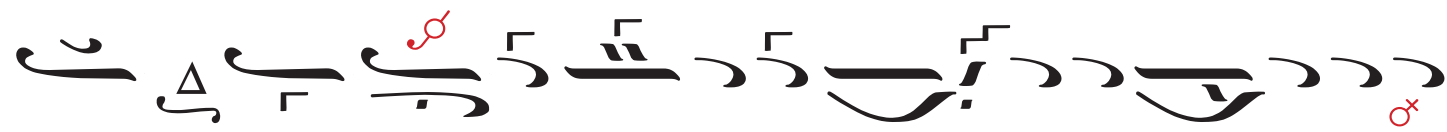
ând că noa a a a a $\quad$ a a a că noa a a ap 
$\sim \nu \frac{e}{r}-1-51 \underbrace{5}=5$ tea îmi es te mi i $\quad$ i $\quad$ i $\quad$ i $\quad$ i

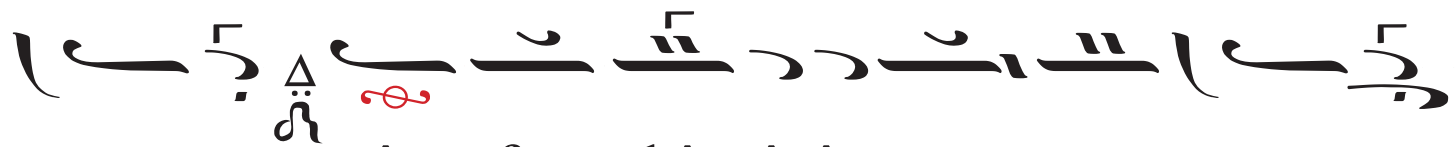
e e în fier bâ â ân ta a a a 5テ>5世. a a a a rea a a $̂$ în fie $e$ er bân ta

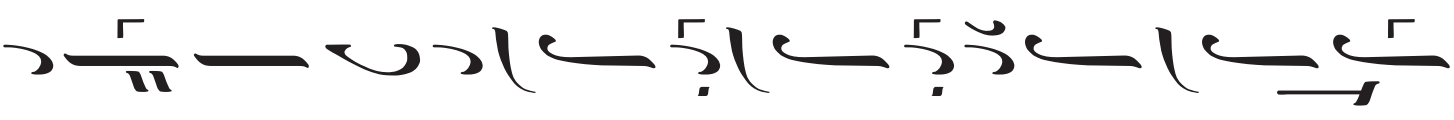
a a a rea a cu ur vi $\mathrm{i}$ i e e e

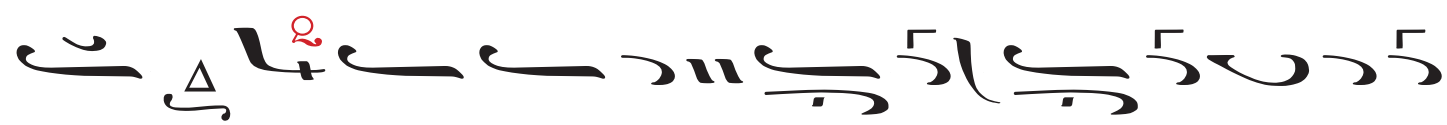
ei în tu ne ca a a a a a a a a 世”

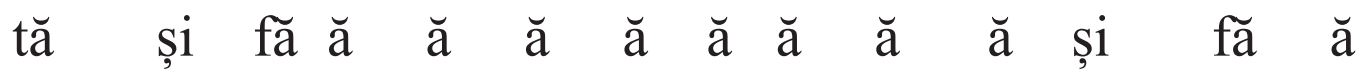

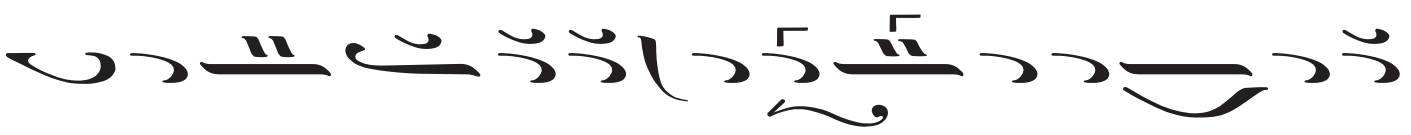
ră

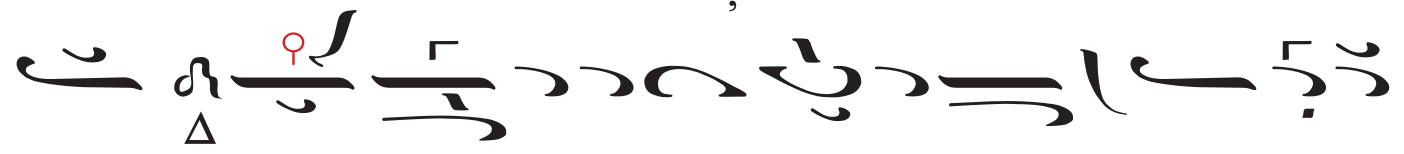
nă po of ta pă ca a a a a tu

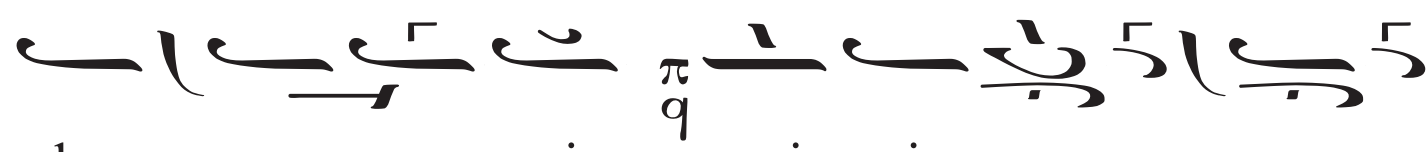
lu u u ui pri i me e e e

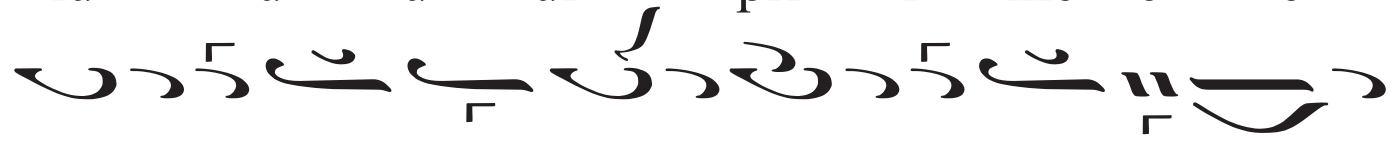
e e eș te iz voa a re e e le e la cri 
$355 \overline{2}$ mi lo or me e e le Ce e la ce sco oți cu u sit? no o rii a pă di in ma a plea a a că ă $\breve{a}$ ă te spre sus pi

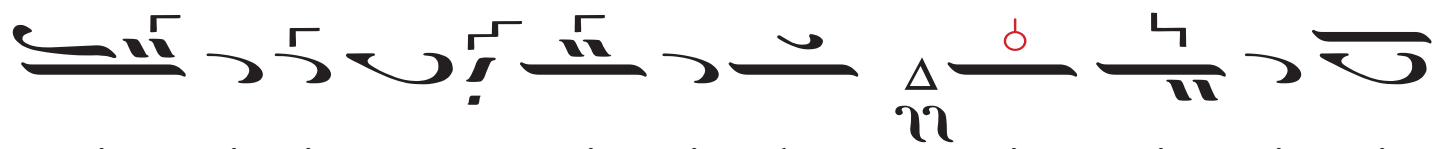

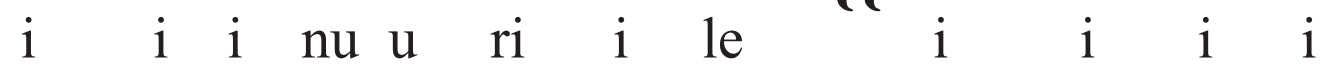

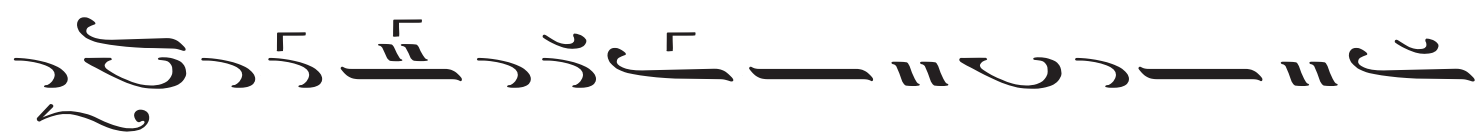
i i i i i i i (n)i ni $i$ mi ii me e e

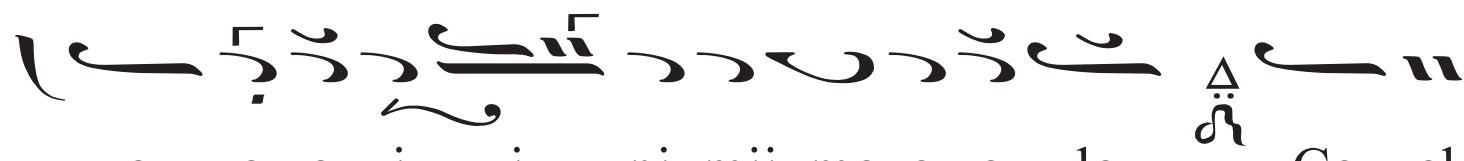
e e e i i ni mii me e e le Ce el $\oiiint 50354$ ce e e e e ai ple e ca a a a a a

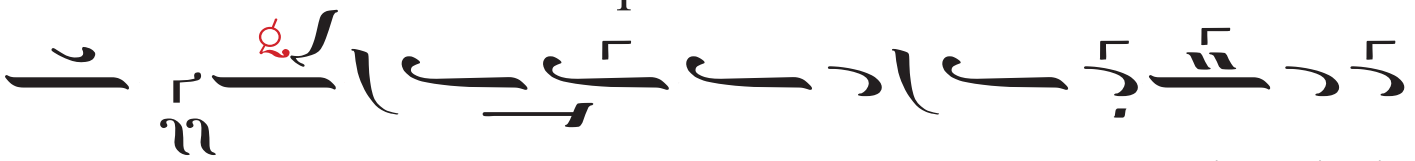
at ce $e$ e $e$ e ru u ri $\quad$ i

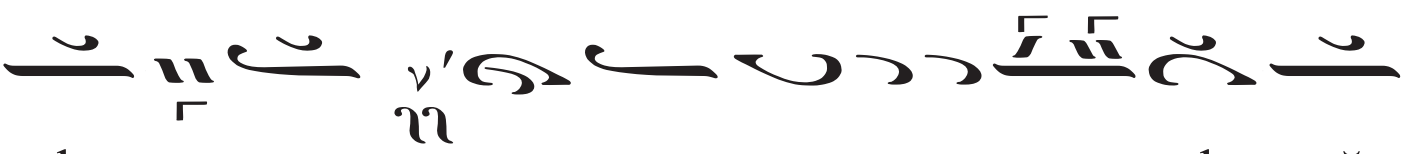
le e e cu nes pu u sa a ple că

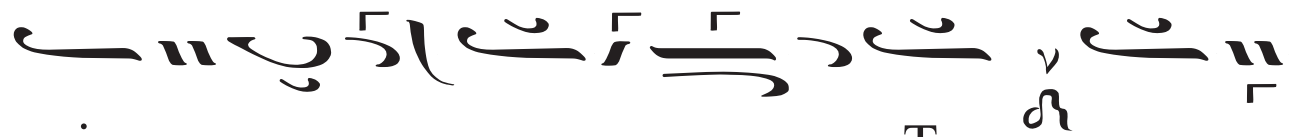

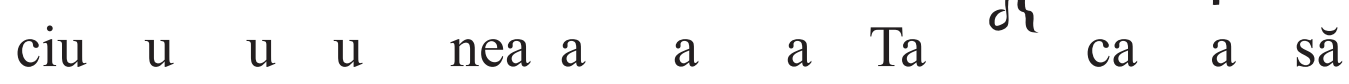




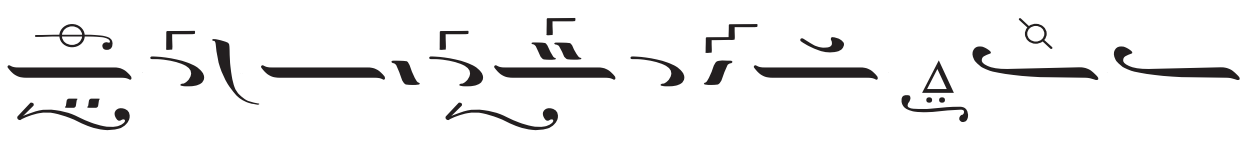

să ru $u \quad u \quad u \quad u \quad u \quad u \quad u t \quad$ prea cu

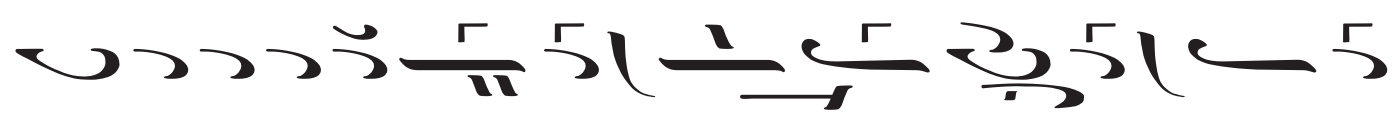

ra a te le Ta a a a le e pi i

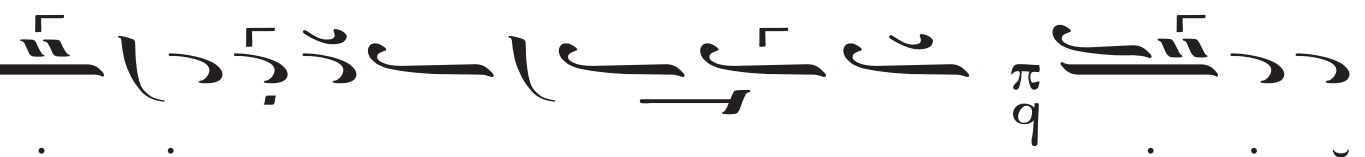

i cioa a a re $\quad$ e $\quad$ e $\quad$ e $\quad$ și $i$ să

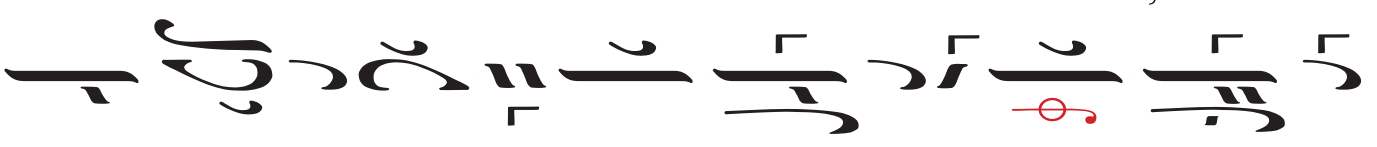

le șterg pe e e e le e ia a a

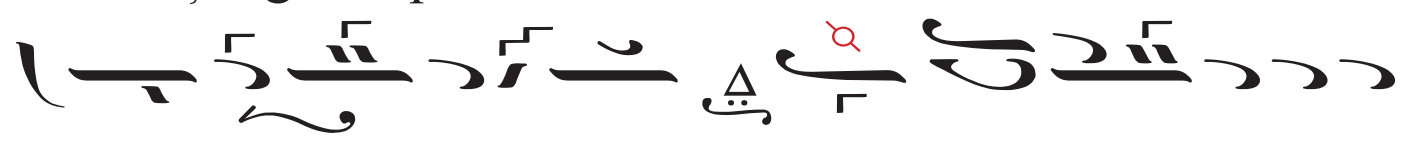

a a a ră ăși cu pă ă ă ă ru

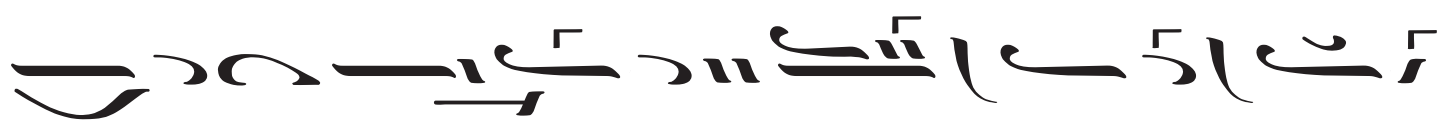

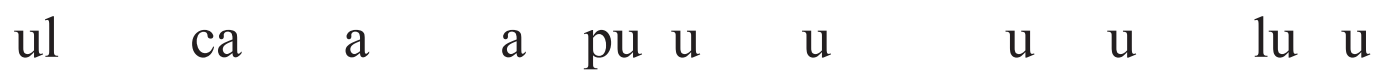

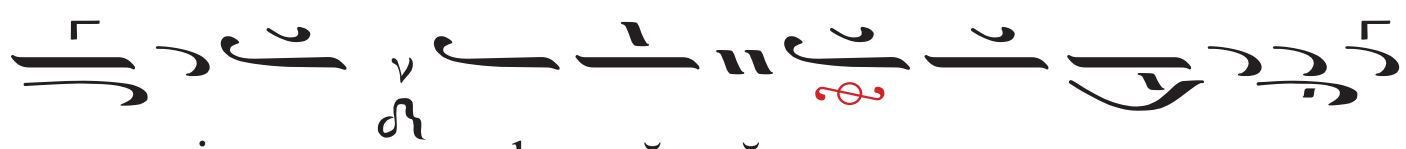

u ui meu al că ă ro ra su u u u

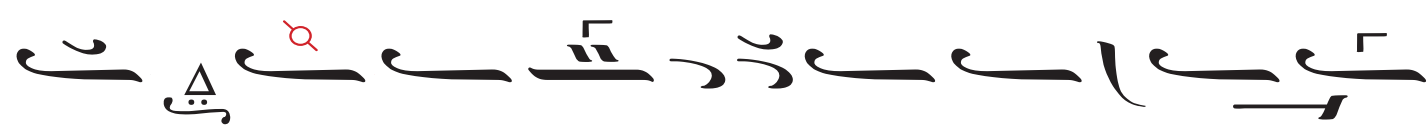

net a $u \quad z i$ in du-l cu $u$ re e

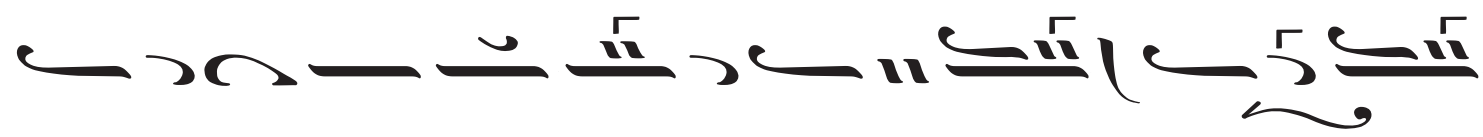

e chi le $\mathrm{E}$ e $\quad$ e $\begin{array}{llllll}\text { va } & \text { a } & \text { a } & \text { a } & \text { a } & \hat{1}\end{array}$

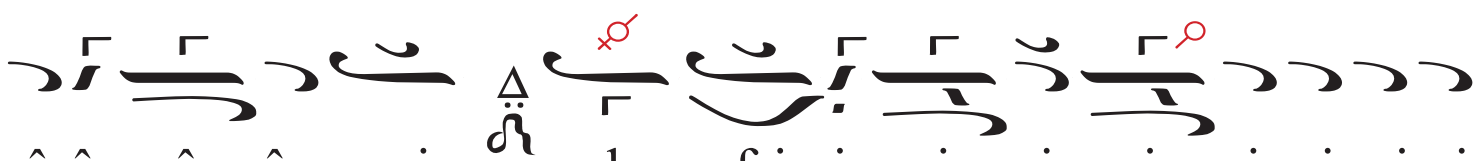
$\hat{1} \hat{i} \hat{i}$ in $\operatorname{rai}$ de fri $i \quad \begin{array}{lllllll} & i & i & i & i & i & i\end{array}$ 


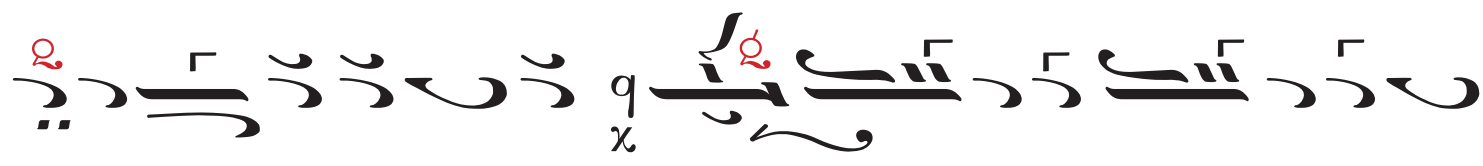

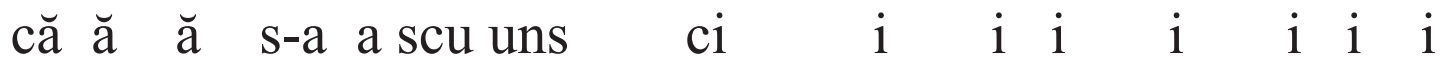

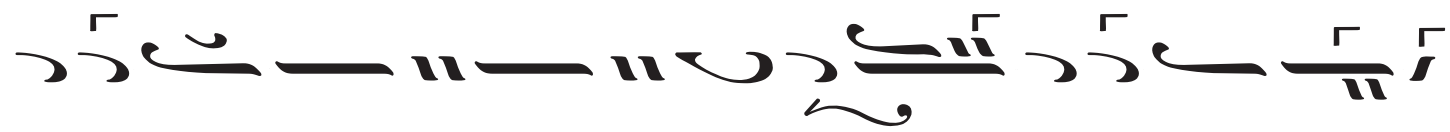
i i ne va a ce er ca a a a a a $a$ a

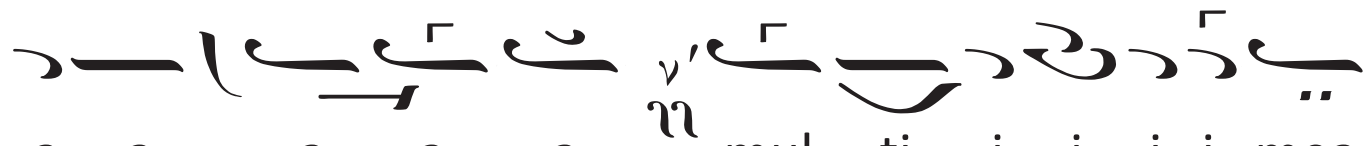
a $\begin{array}{lllllllll} & \text { a } & \text { a } & \text { a } & \text { mul } & \text { i mea }\end{array}$

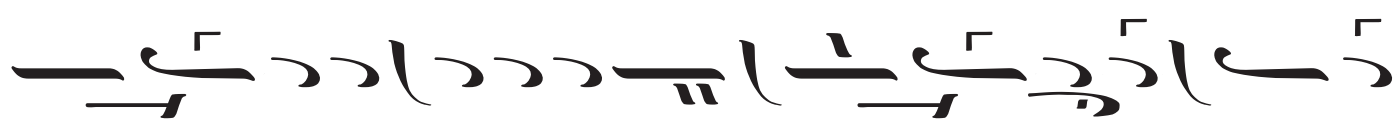
a a a a pă ă ca a a a te e lo o

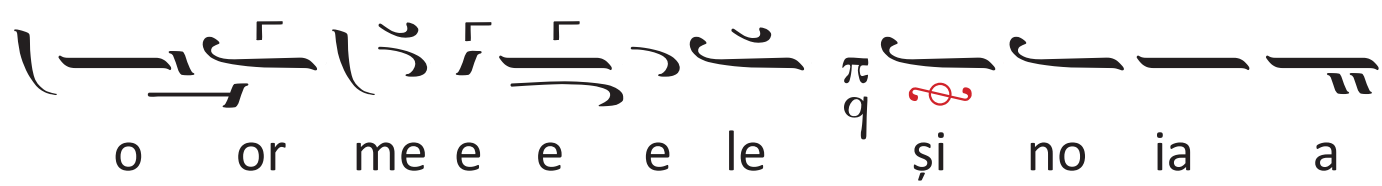

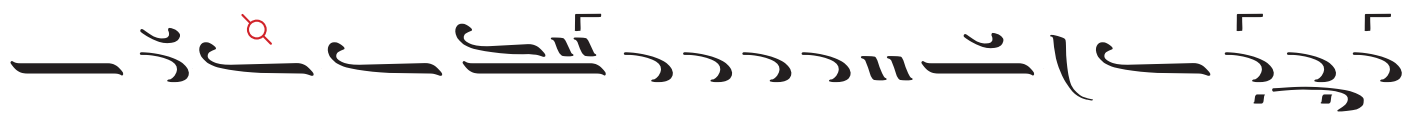
a nul ju de că ă ă ă ți i lor Ta a a a

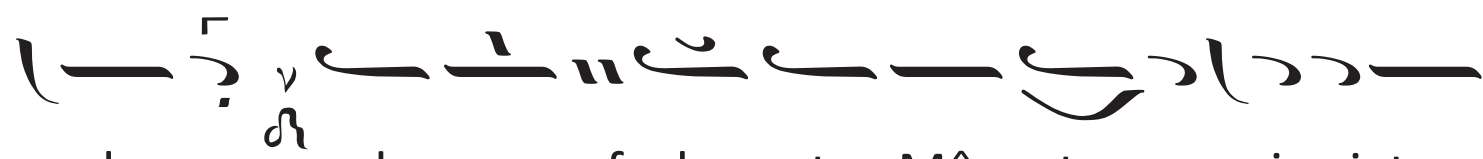

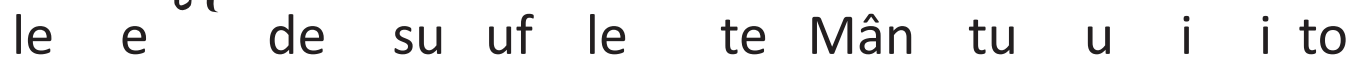

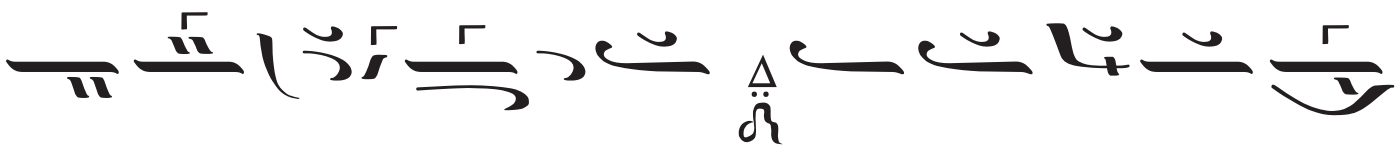
o o ruu u u le iz bă vi to o

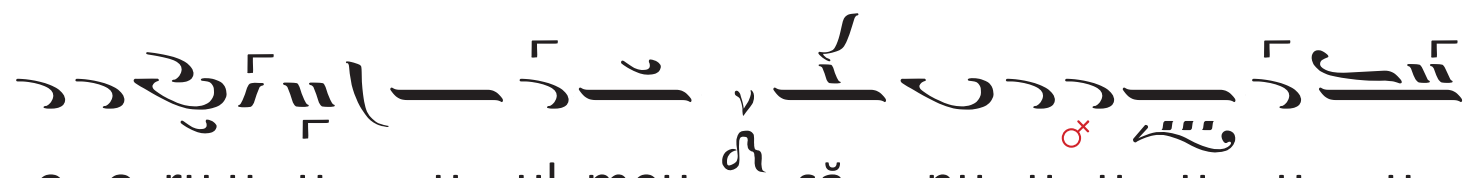
o o ruu u u ul meu or să nu u u u u u 


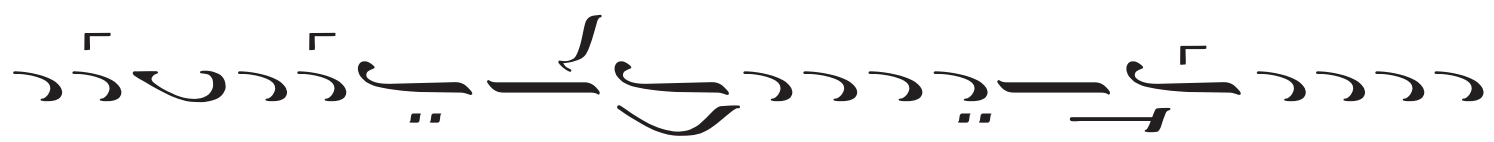

u u u u u mă să nu u măă tre e e e e e eci

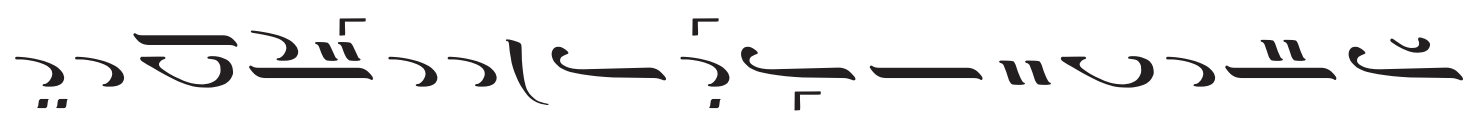
cuve de e e e rea a pre mi i ne e roa a

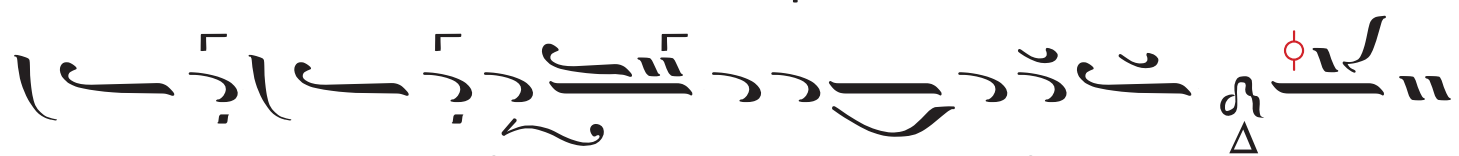
a a a a ba a a a roa a ba Ta $\mathrm{Ce}$ e

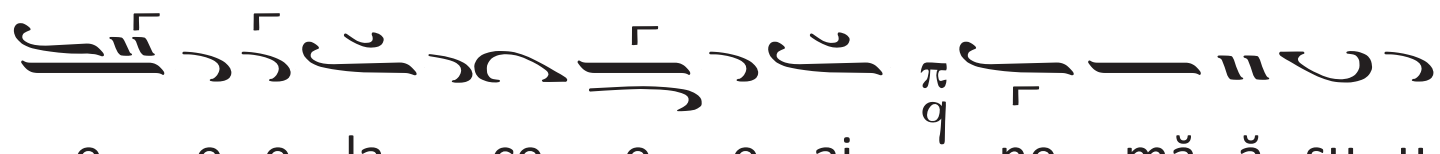
e e e la ce e e ai ne mă ă su u

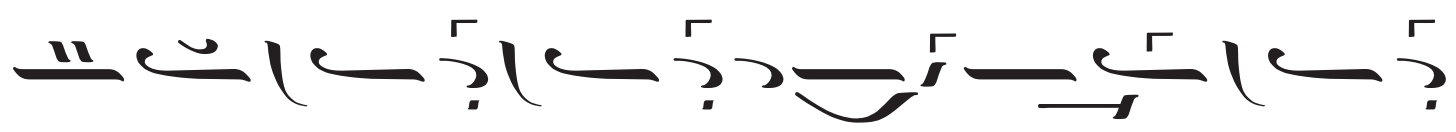

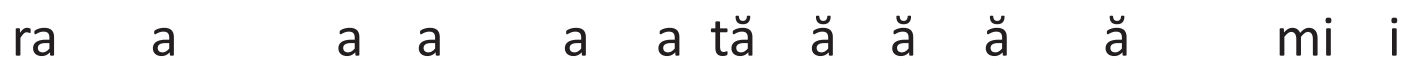

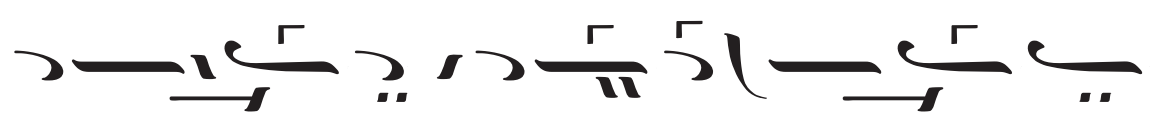

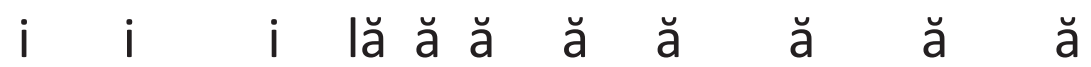

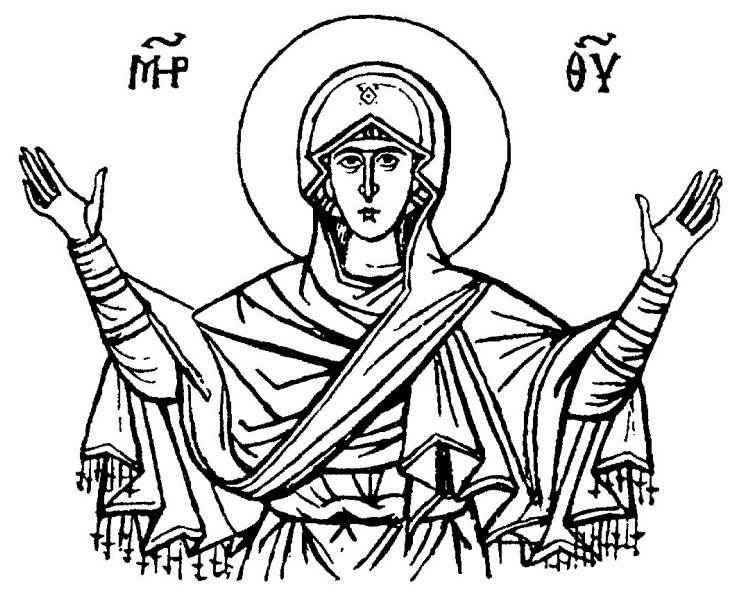

